Organic Contaminants Associated with Suspended Sediment Collected During Five Cruises of the Mississippi River and its Principal Tributaries, May 1988 to June 1990

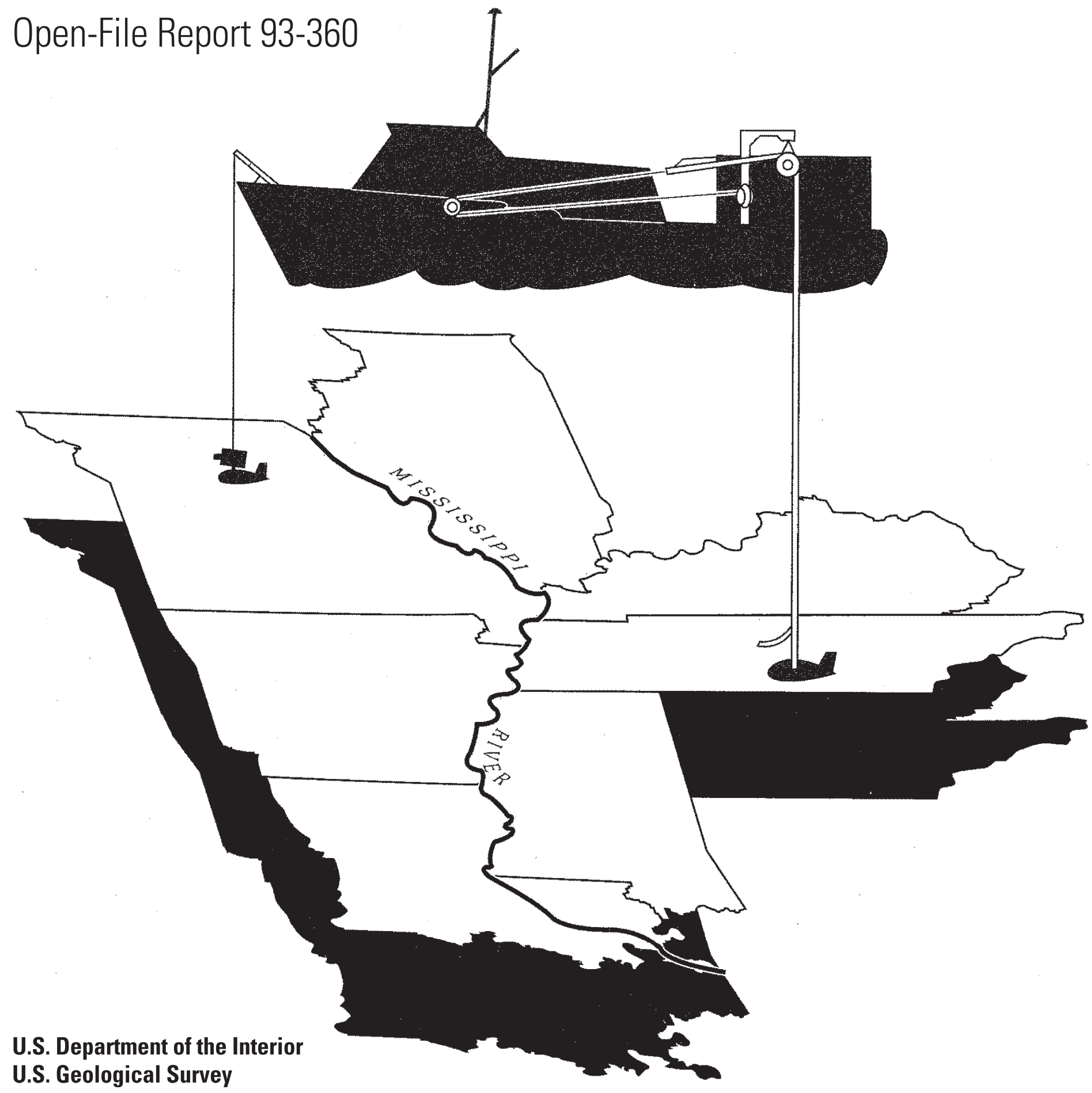





\title{
Organic Contaminants Associated with Suspended Sediment Collected During Five Cruises of the Mississippi River and its Principal Tributaries, May 1988 to June 1990
}

By Colleen E. Rostad, LaDonna M. Bishop, Geoffrey S. Ellis, Thomas J. Leiker,

\author{
Stephanie G. Monsterleet, and Wilfred E. Pereira
}

Open-File Report 93-360 


\title{
U.S. Department of the Interior \\ Gale A. Norton, Secretary \\ U.S. Geological Survey \\ Charles G. Groat, Director
}

\section{U.S. Geological Survey, Reston, Virginia: 2004}

\author{
For sale by U.S. Geological Survey, Information Services \\ Box 25286, Denver Federal Center \\ Denver, CO 80225 \\ For more information about the USGS and its products: \\ Telephone: 1-888-ASK-USGS \\ World Wide Web: http://www.usgs.gov/
}

\footnotetext{
Any use of trade, product, or firm names in this publication is for descriptive purposes only and does not imply endorsement by the U.S. Government.

Although this report is in the public domain, permission must be secured from the individual copyright owners to reproduce any copyrighted materials contained within this report.
} 


\section{Contents}

Abstract
Introduction
Purpose and Scope
Acknowledgments
Methods $\quad$ Sample collection
$\quad$ Sample analysis
Organic Contaminant Data
Literature Cited

\section{Figures}

1. Map showing location of sampling sites on the Mississippi River and its principal tributaries (modified from Moody and Meade, 1992 and 1993).

\section{Tables}

1. Cross-section sampling sites during cruises of May-June 1988, March-April 1989, June 1989, February-March 1990, and May-June 1990.

2. Mississippi River suspended-sediment concentration (smaller than 63 micrometer), water discharge, and organic-carbon content.

3. Instrumental analytical detection limit for 1 microliter of standard solution.

4. Percent recovery for triplicate samples spiked at 20 nanograms of target compound per gram suspended sediment.

5. Halogenated organic compounds found in suspended-sediment samples collected during the May-June 1988 cruise.

6. Halogenated organic compounds found in suspended-sediment samples collected during the March-April 1989 cruise

7. Halogenated organic compounds found in suspended-sediment samples collected during the June 1989 cruise.

8. Halogenated organic compounds found in suspended-sediment samples collected during the February-March 1990 cruise.

9. Halogenated organic compounds found in suspended-sediment samples collected during the May-June 1990 cruise.

10. Average relative standard deviation, in percent, for replicate analyses.

11. Halogenated organic compounds in suspended-sediment depth-integrated and pumped samples collected June 7, 1989 from the Missouri River at Hermann, Missouri.

12. Hydrophobic U.S. Environmental Protection Agency priority pollutants detected in suspended-sediment samples collected during the June 1989 cruise.

13. Hydrophobic U.S. Environmental Protection Agency priority pollutants detected in suspended-sediment samples collected during the February-March 1990 cruise. 


\section{Tables-Continued}

14. Semiquantitative screening for organochlorine compounds and herbicides found in suspended-sediment samples collected during the June 1989 cruise.

15. Semiquantitative screening for organochlorine compounds and herbicides found in suspended-sediment samples collected during the February-March 1990 cruise.

\section{Conversion Factors}

\begin{tabular}{|c|c|c|}
\hline Multiply & By & To obtain \\
\hline \multicolumn{3}{|c|}{ Length } \\
\hline centimeter $(\mathrm{cm})$ & 0.3937 & inch (in.) \\
\hline millimeter (mm) & 0.03937 & inch (in.) \\
\hline meter $(\mathrm{m})$ & 3.281 & foot $(\mathrm{ft})$ \\
\hline kilometer (km) & 0.6214 & mile (mi) \\
\hline kilometer (km) & 0.5400 & mile, nautical (nmi) \\
\hline meter $(\mathrm{m})$ & 1.094 & $\operatorname{yard}(\mathrm{yd})$ \\
\hline \multicolumn{3}{|c|}{ Volume } \\
\hline liter $(\mathrm{L})$ & 0.2642 & gallon (gal) \\
\hline cubic meter $\left(\mathrm{m}^{3}\right)$ & 264.2 & gallon (gal) \\
\hline cubic meter $\left(\mathrm{m}^{3}\right)$ & 0.0002642 & million gallons (Mgal) \\
\hline cubic centimeter $\left(\mathrm{cm}^{3}\right)$ & 0.06102 & cubic inch $\left(\right.$ in $\left.^{3}\right)$ \\
\hline liter $(\mathrm{L})$ & 61.02 & cubic inch $\left(\mathrm{in}^{3}\right)$ \\
\hline cubic meter $\left(\mathrm{m}^{3}\right)$ & 35.31 & cubic foot $\left(\mathrm{ft}^{3}\right)$ \\
\hline cubic meter $\left(\mathrm{m}^{3}\right)$ & 1.308 & cubic yard $\left(\mathrm{yd}^{3}\right)$ \\
\hline cubic meter $\left(\mathrm{m}^{3}\right)$ & 0.0008107 & acre-foot (acre-ft) \\
\hline \multicolumn{3}{|c|}{ Flow rate } \\
\hline cubic meter per second $\left(\mathrm{m}^{3} / \mathrm{s}\right)$ & 70.07 & acre-foot per day (acre-ft/d) \\
\hline meter per second $(\mathrm{m} / \mathrm{s})$ & 3.281 & foot per second $(\mathrm{ft} / \mathrm{s})$ \\
\hline cubic meter per second $\left(\mathrm{m}^{3} / \mathrm{s}\right)$ & 35.31 & cubic foot per second $\left(\mathrm{ft}^{3} / \mathrm{s}\right)$ \\
\hline cubic meter per day $\left(\mathrm{m}^{3} / \mathrm{d}\right)$ & 35.31 & cubic foot per day $\left(\mathrm{ft}^{3} / \mathrm{d}\right)$ \\
\hline liter per second $(\mathrm{L} / \mathrm{s})$ & 15.85 & gallon per minute (gal/min) \\
\hline cubic meter per day $\left(\mathrm{m}^{3} / \mathrm{d}\right)$ & 264.2 & gallon per day $(\mathrm{gal} / \mathrm{d})$ \\
\hline cubic meter per second $\left(\mathrm{m}^{3} / \mathrm{s}\right)$ & 22.83 & million gallons per day $(\mathrm{Mgal} / \mathrm{d})$ \\
\hline \multicolumn{3}{|c|}{ Mass } \\
\hline $\operatorname{gram}(\mathrm{g})$ & 0.03527 & ounce, avoirdupois (oz) \\
\hline kilogram (kg) & 2.205 & pound, avoirdupois (lb) \\
\hline megagram $(\mathrm{Mg})$ & 1.102 & ton, short $(2,000 \mathrm{lb})$ \\
\hline megagram (Mg) & 0.9842 & ton, long $(2,240 \mathrm{lb})$ \\
\hline metric ton per day & 1.102 & ton per day (ton/d) \\
\hline megagram per day $(\mathrm{Mg} / \mathrm{d})$ & 1.102 & ton per day (ton/d) \\
\hline $\begin{array}{l}\text { megagram per day per square } \\
\text { kilometer }\left[(\mathrm{Mg} / \mathrm{d}) / \mathrm{km}^{2}\right]\end{array}$ & 2.8547 & $\begin{array}{l}\text { ton per day per square mile } \\
{\left[(\text { ton } / \mathrm{d}) / \mathrm{mi}^{2}\right]}\end{array}$ \\
\hline megagram per year (Mg/yr) & 1.102 & ton per year (ton/yr) \\
\hline metric ton per year & 1.102 & ton per year (ton/yr) \\
\hline \multicolumn{3}{|c|}{ Hydraulic conductivity } \\
\hline meter per day $(\mathrm{m} / \mathrm{d})$ & 3.281 & foot per day $(\mathrm{ft} / \mathrm{d})$ \\
\hline \multicolumn{3}{|c|}{ Hydraulic gradient } \\
\hline meter per kilometer $(\mathrm{m} / \mathrm{km})$ & 5.27983 & foot per mile $(\mathrm{ft} / \mathrm{mi})$ \\
\hline
\end{tabular}

Temperature in degrees Celsius $\left({ }^{\circ} \mathrm{C}\right)$ may be converted to degrees Fahrenheit $\left({ }^{\circ} \mathrm{F}\right)$ as follows: 


\title{
Organic Contaminants Associated with Suspended Sediment Collected During Five Cruises of the Mississippi River and its Principal Tributaries, May 1988 to June 1990
}

\author{
By Colleen E. Rostad, LaDonna M. Bishop, Geoffrey S. Ellis, Thomas J. Leiker, Stephanie G. Monsterleet, and \\ Wilfred E. Pereira
}

\section{Abstract}

Suspended-sediment samples were obtained from sites along the Mississippi River and its principal tributaries to determine the presence of halogenated hydrophobic organic compounds on the suspended sediment smaller than 63 micrometers. Sample collection involved pumping discharge-weighted volumes of river water along a cross section of the river into a continuous-flow centrifuge to isolate the suspended sediment. The suspended sediment was analyzed by gas chromatography/mass spectrometry for pentachlorobenzene, hexachlorobenzene, pentachloroanisole, chlorothalonil, pentachlorophenol, dachthal, chlordane, nonachlor, and penta-, hexa-, hepta-, and octachlorobiphenyls. Samples collected during June 1989 and February-March 1990 also were analyzed for U.S. Environmental Protection Agency priority pollutants, including polycyclic aromatic hydrocarbons, phthalate esters, and triazines. Samples were collected at sites on the Mississippi River from above St. Louis, Missouri to below New Orleans, Louisiana, and on the Illinois, Missouri, Ohio, Wabash, Cumberland, Tennessee, White, Arkansas, and Yazoo Rivers. Masses of selected halogenated hydrophobic organic compounds associated with the suspended sediment at each site are presented in this report in tabular format, along with suspended-sediment concentration, water discharge, and organic-carbon content.

\section{Introduction}

The Mississippi River is the major river of North America, draining 2.97 million square kilometers, or 40 percent of the contiguous United States, and parts of two provinces in Canada. It is an important resource for food, transportation, drinking water, recreation, and irrigation. The sediment load of the Mississippi River has decreased substantially over the last 50 years, mostly because of the extensive series of dams built on its tributaries (Meade and Parker, 1985; Keown and others, 1986; Meade and others, 1990).
There have been few studies of the organic compounds associated with suspended sediment. One study on sites in Louisiana reported that almost all compounds were below detection limits of $1 \mathrm{ng} / \mathrm{g}$ (Demas and Curwick, 1987; 1988). Suspended-sediment studies on other rivers also reported target compounds to be present below the detection limit of $4 \mathrm{ng} / \mathrm{g}$ (Merriman, 1988). Distribution of the organic compounds on the suspended sediment in the entire lower Mississippi River from above St. Louis, Missouri to below New Orleans, Louisiana, however, has not been previously addressed. Consequently, an assessment of the occurrence and distribution of organic contaminants is needed to provide a basis for evaluating contaminant transport associated with the suspended sediment.

Four interactive factors that have substantially affected the suspended-sediment regime over this same period of time include increases in: (1) agriculture; (2) commerce and industry; (3) transportation networks; and (4) population and urbanization (Keown and others, 1981). Industrial discharge and nonpoint-source agricultural runoff have increased the loads of anthropogenic organic compounds in the river. Some of these compounds remain in the aqueous phase and have been investigated throughout the river (Schafer and others, 1969; DeLeon and others, 1986; Pereira and Rostad, 1990). Some of the lesssoluble compounds adsorb onto bed sediments and also have been investigated (Barthel and others, 1969; Lytle and Lytle, 1990). Most previous studies have focused only on the transport and deposition of the suspended sediment itself (Everett, 1971; Robbins, 1976; Wells, 1980; Meade and Parker, 1985; Grayman, 1985; Meade and others, 1990).

Suspended-sediment composition is affected by surfacesoil runoff and by deposition and resuspension, which are dependent upon the ever-changing flow dynamics of the river. A comprehensive compilation of environmental characteristics and history of suspended sediment in the Mississippi River was provided by Keown and others (1981). Annually, the Ohio River contributes about 50 percent of the water but only about 37 percent of the sediment in the Mississippi River. In contrast, about 15 percent of the water and at least 40 percent of the sediment in the Mississippi River are contributed by 
the Missouri River (Moody and Meade, 1992). The Missouri River mainly drains agricultural areas; the Ohio River drains more industrial areas. Physical differences in suspended sediment and differences in chemical inputs from these two major tributaries may affect the distribution of organic compounds on the suspended sediment in the Mississippi River.

The Mississippi River Study of the U.S. Geological Survey is a multidisciplinary project to quantify environmental facets of an active river system, such as water and sediment transport, tributary mixing, and water quality. Specific aspects for study included trace metals, nutrients, pesticides, fecal sterols, surfactants, and halogenated organic compounds. The objectives of the portion of the study focusing on halogenated organic compounds included:

1. To procure large enough suspended-sediment sample (smaller than 63 micron) to enable detection of target organic compounds.

2. To extract suspended sediment in order to isolate target organic compounds.

3. To utilize sensitive, specific gas chromatography/negative chemical ionization/mass spectrometry to compensate for complex matrix effects in the analysis for the target organic compounds.

4. To determine the occurrence and distribution of halogenated organic compounds on the suspended sediment in the Mississippi River.

The variety of organic compounds and the trace levels present associated with the suspended sediment necessitate large sample sizes (hundreds of liters) to provide sufficient sample for analysis. Representative suspended sediment in suitable quantities for analysis of trace toxic organic compounds is much more difficult to obtain than the readily available bed sediments. In order to determine transport of organic contaminants on the suspended sediment in the Mississippi River, representative samples at selected sites were combined with information on the water discharge measured at each site.

\section{Purpose and Scope}

The purpose of this report is to describe the distribution of halogenated anthropogenic and U.S. Environmental Protection Agency (EPA) priority pollutant (Federal Register, 1980) compounds found on the suspended sediment smaller than 63 micron at selected sites on the Mississippi River for five cruises over a 2-year period, from May 1988 to June 1990.

Suspended sediment was obtained from sites along the Mississippi River and its principal tributaries as part of an ongoing, multidisciplinary study by the U.S. Geological Survey (USGS) (Leenheer and others, 1989; Meade and Stevens, 1990; Pereira and others, 1990; Rees and Ranville, 1990; Taylor and others, 1990). Five sampling cruises during May-June 1988, March-April 1989, June 1989, February-March 1990, and May-June 1990 included a variety of flow conditions.
The sampling cruises on the Mississippi River covered over $1,700 \mathrm{~km}$. Sampling locations included sites on the mainstem of the Mississippi River, as well as on the Illinois, Missouri, Ohio, White, Arkansas, and Yazoo Rivers.

The entire Midwest was in a severe drought during the sampling cruise in May-June 1988. For May and June 1988 , total flow at the 181 USGS stream index stations in the conterminous United States and southern Canada was the lowest recorded for May and June in the previous 6 years (U.S. Geological Survey, and Canada, Department of the Environment, 1988a and 1988b). The later cruises in 1989 and 1990 were planned to sample the Mississippi River at high water. Detailed hydrologic conditions are given by Moody and Meade (1992 and 1993) for all cruises in this report.

Suspended sediment was collected and analyzed for organic compounds. The analytical protocol was chosen to focus on halogenated hydrophobic anthropogenic organic compounds. By combining large sample sizes with specialized analytical techniques, lower detection limits than those previously mentioned were achieved in this study. The use of highly specific, very sensitive gas chromatography/negative chemical ionization/mass spectrometry enabled a detection limit of $0.05 \mathrm{ng} / \mathrm{g}$ for most compounds in spite of the complex sample matrix. The compounds included pentachlorobenzene (present in hexachlorobenzene formulations), hexachlorobenzene (fungicide), pentachloroanisole (transformation product of pentachlorophenol), chlorothalonil (fungicide), pentachlorophenol (wood preservative and general herbicide), dachthal (preemergent herbicide), chlordane (insecticide), nonachlor (present in technical chlordane formulations), and penta-, hexa-, hepta-, and octachlorobiphenyls (PCBs, industrial chemicals).

For each cruise, masses of selected halogenated hydrophobic organic compounds were measured on the suspended sediment analyzed from each site. These data are presented in this report in tabular format, along with water discharge, suspended-sediment concentration, and percent organic carbon on the sediment. In addition, EPA priority pollutants were determined in selected samples from the June 1989 and February-March 1990 sampling cruises.

\section{Acknowledgments}

Suspended-sediment sampling of this scale requires the dedicated assistance of many individuals, particularly for the field work. The authors thank the following people for providing data and helping collect and process the samples that we analyzed: T. Brinton, P. Brown, J. Garbarino, J. Leenheer, D. Martin, R. Meade, J. Moody, T. Noyes, D. Peart, T. Rees, J. Ranville, J. Seeley, R. Stallard, H. Stevens, H. Taylor, and T. Willoughby. The authors also thank the crew of Research Vessel ACADIANA, owned and operated by Louisiana Universities Marine Consortium: Captains L. Black, C. LeBoeuf, W. Simoneaux, and S. Rabalais, and crewmen W. DeLaune, C. Guidry, D. Lapreyrouse, and R. Cutting. 


\section{Methods}

\section{Sample collection}

Representative, discharge-weighted, suspended-sediment samples were collected during May-June 1988, March-April 1989, June 1989, February-March 1990, and May-June 1990 at various sites along the Mississippi River and its principal tributaries by using techniques described by Moody and Meade (1992 and 1993). The sampling sites for each cruise are shown on figure 1 and listed in table 1.

A Lagrangian sampling scheme (Nordin and others, 1983; Meade and Stevens, 1990) was used that attempted to follow the same parcel of water as it moved down the river channel, as determined by the mean water velocity. The Lagrangian sampling scheme was most successfully attained on the cruises of May-June 1988 and February-March 1990. On the first of these, the Mississippi River velocities were slow enough that tributaries could be sampled without interrupting the Lagrangian continuity; the second cruise was specifically designed to follow the late-winter discharge of the Ohio River from Uniontown, Ky., to Belle Chasse, La., and therefore no tributaries were sampled (Moody, 1993; Moody and Meade, 1993).

Two types of suspended-sediment samples were collected: depth-integrated composite sample (8 to $139 \mathrm{~L}$ ) and a larger (299 to 916 L) pumped composite sample. Analyses listed in this report are for the pumped composite sample.

The depth-integrated composite samples were collected concurrently with the pumped composite samples, according to procedures described by Meade (1985), Meade and Stevens (1990), and Moody and Meade (1992). The discharge-weighted concentration of suspended sediment finer than 63 micrometers in the river at each site was determined by filtration through paired, preweighed Millipore filters (see Moody and Meade, 1992 and 1993 for details). The concentration of suspended sediment varies with depth. The sample taken for determination of the suspended-sediment concentration, collected concurrently with the pumped samples was discharge-weighted and depth-integrated according to procedures described by Meade (1985), Meade and Stevens (1990), and Moody and Meade (1992 and 1993). As such, this latter sample is more representative of the total suspended-sediment transport in the river than the pumped sample collected for organic analysis and therefore was used to determine the total suspended-sediment concentration. This discharge-weighted concentration of suspended sediment and the discharge as determined by the depth-integration method described by Moody and Troutman (1992) are presented in table 2. Further details of the water-discharge and suspended-sediment measurements are reported by Moody and Meade (1992).

At each sampling cross section, the water discharge was estimated at each of 5-30 equally spaced verticals, using the depth profile of the river and five depth-integrated velocity measurements. A discharge-weighted, pumped sample that was proportional to the estimated fractional discharge at each vertical was collected (Moody, 1993; Moody and Meade, 1993).

The 17-m research vessel from which the samples were collected was positioned in the river at each of as many as 30 verticals in the cross section by using microwave trisponders located on each bank. The discharge-weighted pumped sample was collected at each vertical from one-half the depth or $5 \mathrm{~m}$, whichever was less. The maximum possible sampling depth for the equipment used was $5 \mathrm{~m}$. The water was pumped through FEP Teflon tubing rigidly positioned parallel to the flow by using an air-driven, double-diaphragm Teflon pump, into a 63-micron nickel-mesh sieve. The water then flowed into a large $(40 \mathrm{~L})$ glass funnel, which provided constant head pressure into a continuous-flow, high-speed centrifuge (Sharples AS-12). The centrifuge was operated at 16,000 revolutions per minute and is described in detail by Leenheer and others (1989) and Rees and others (1991). To ensure high recovery efficiency of suspended sediment, the 2-L/min flow rate through the centrifuge was one-half that used by Ongley and Blachford (1982), who reported preferential losses of the organic-rich portion over the mineral-rich suspended sediment at $4 \mathrm{~L} / \mathrm{min}$. Sediment particles as small as $370 \mathrm{~nm}$ were recovered in the centrifuge (Rees and Ranville, 1990).

All exposed centrifuge surfaces were coated with or directly machined from TFA or FEP Teflon to minimize sample contamination. The suspended sediment from a total of 299 to $916 \mathrm{~L}$ of water was deposited on the cylindrical wall of the centrifuge bowl, which was lined with a removable sheet of 0.35-mm-thick FEP Teflon. The liner was easily transferred from the bowl, using Teflon tweezers and FEP Teflon gloves, into an FEP Teflon sample bag, where the sediment sample was resuspended by gentle massage of the liner from outside the bag. The suspended sediment from the 299 to $916 \mathrm{~L}$ of river water was then contained in 1 to $2 \mathrm{~L}$ of water. This solution was transferred to 1-L glass jars, preserved with five drops of chloroform, refrigerated, transported on ice to the laboratory, allowed to settle for at least 1 week, aspirated to remove the supernatant, and air-dried in the original container.

Comparative studies (J.A. Moody and R.H. Meade, U.S. Geological Survey, written commun., 1992) indicated that the size distribution of suspended particles smaller than 63 micrometers in the pumped samples was virtually identical to that in the composite depth-integrated samples; thus, the pumped sample is representative of the fine fraction (smaller than 63 micrometers) of suspended sediment transported by the river.

The organic carbon content in percent (table 2) for the analyzed suspended sediment, was determined by Huffman Laboratories, Golden, Colo. Duplicate samples varied less than 2 percent from the mean. These data enable calculation of loads. 


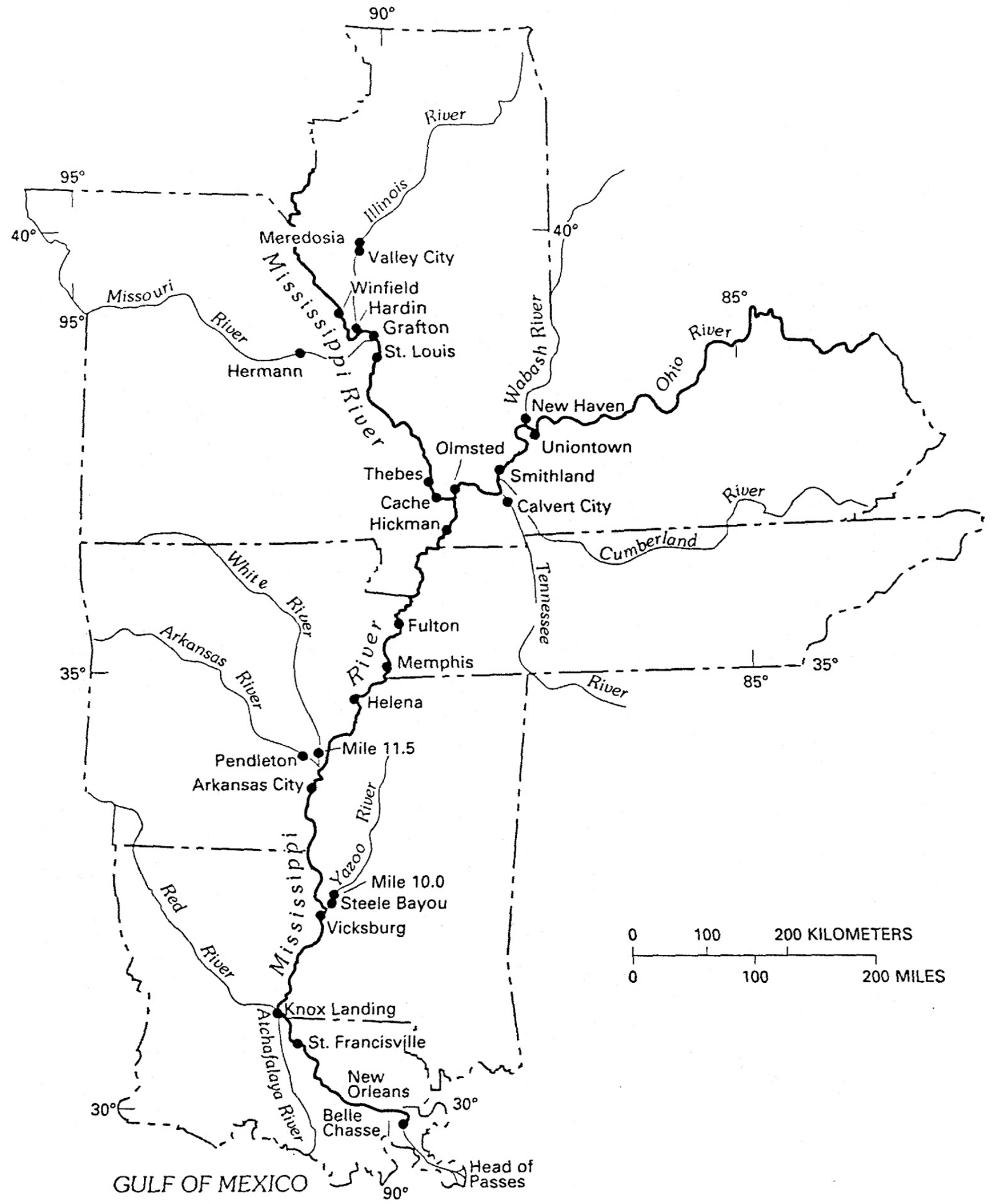

Figure 1. Location of sampling sites on the Mississippi River and its principal tributaries (modified from Moody and Meade, 1992 and 1993). 
Table 1. Cross-section sampling sites during cruises of May-June 1988, March-April 1989, June 1989, February-March 1990, and May-June 1990.

[X designates that the cross section was sampled]

\begin{tabular}{|c|c|c|c|c|c|c|}
\hline Sampling site & River mile $^{1}$ & $\begin{array}{c}\text { May-June } \\
1988\end{array}$ & $\begin{array}{c}\text { Mar-April } \\
1989\end{array}$ & June 1989 & $\begin{array}{c}\text { Feb-Mar } \\
1990\end{array}$ & $\begin{array}{c}\text { May-June } \\
1990\end{array}$ \\
\hline Mississippi River near Winfield, Mo. & UM 239.2 & $\mathrm{X}$ & $\mathrm{X}$ & $\mathrm{X}$ & & \\
\hline Illinois River below Meredosia, Ill. & IL 67.2 & $\mathrm{X}$ & & & & \\
\hline Illinois River at Valley City, Ill. & IL 61.0 & & & & & $\mathrm{X}$ \\
\hline Illinois River at Hardin, Ill. & IL 21.8 & & $\mathrm{X}$ & $\mathrm{X}$ & & \\
\hline Mississippi River below Grafton, Ill. & UM 214.6 & & & & & $\mathrm{X}$ \\
\hline Missouri River at Hermann, Mo. & MO 97.9 & $\mathrm{X}$ & $\mathrm{X}$ & $\mathrm{X}$ & & \\
\hline Mississippi River at St. Louis, Mo. & UM 179.3 & $\mathrm{X}$ & $\mathrm{x}$ & $\mathrm{X}$ & & \\
\hline Mississippi River at Thebes, Ill. & UM 43.9 & $\mathrm{X}$ & $\mathrm{X}$ & $\mathrm{X}$ & & $\mathrm{X}$ \\
\hline Mississippi River near Cache, Ill. & UM 14.8 & & & & $\mathrm{X}$ & \\
\hline Ohio River at Uniontown, Ky. & OH 842.4 & & & & $\mathrm{x}$ & \\
\hline Wabash River near New Haven, Ill. & WA 13.8 & & & & $\mathrm{X}$ & \\
\hline Cumberland River near Smithland, Ky. & CU 6.8 & & & & $\mathrm{X}$ & \\
\hline Tennessee River near Calvert City, Ky. & TE 11.1 & & & & $\mathrm{X}$ & \\
\hline Ohio River at Olmsted, Ill. & OH 965.0 & $\mathrm{X}$ & $\mathrm{X}$ & $\mathrm{X}$ & $\mathrm{X}$ & $\mathrm{X}$ \\
\hline Mississippi River below Hickman, Ky. & LM 916.8 & $\mathrm{X}$ & $\mathrm{X}$ & $\mathrm{X}$ & $\mathrm{x}$ & \\
\hline Mississippi River at Fulton, Tenn. & LM 777.3 & $\mathrm{X}$ & & $\mathrm{x}$ & & \\
\hline Mississippi River below Fulton, Tenn. & LM 773.5 & & $\mathrm{X}$ & & $\mathrm{X}$ & \\
\hline Mississippi River below Memphis, Tenn. & LM 731.2 & & & & & $\mathrm{X}$ \\
\hline Mississippi River at Helena, Ark. & LM 663.9 & $\mathrm{X}$ & $\mathrm{X}$ & $\mathrm{X}$ & $\mathrm{X}$ & \\
\hline White River at Mile 11.5, Ark. & WH 11.5 & $\mathrm{X}$ & $\mathrm{X}$ & $\mathrm{X}$ & & \\
\hline Arkansas River at Pendleton, Ark. & AR 22.4 & & $\mathrm{X}$ & $\mathrm{X}$ & & \\
\hline Mississippi River above Arkansas City, Ark. & LM 566.0 & $\mathrm{X}$ & $\mathrm{X}$ & $\mathrm{X}$ & $\mathrm{X}$ & \\
\hline Mississippi River below Arkansas City, Ark. & LM 551.7 & & & & & $\mathrm{X}$ \\
\hline Yazoo River at Mile 10.0, Miss. & YZ 10.0 & $\mathrm{X}$ & & & & \\
\hline Yazoo River below Steele Bayou, Miss. & YZ 9.0 & & $\mathrm{X}$ & $\mathrm{X}$ & & $\mathrm{X}$ \\
\hline Mississippi River below Vicksburg, Miss. & LM 433.4 & $\mathrm{X}$ & $\mathrm{X}$ & $\mathrm{X}$ & $\mathrm{X}$ & $\mathrm{X}$ \\
\hline Old River Outflow Channel near Knox Landing, Ark. & OR 5.5 & $\mathrm{X}$ & $\mathrm{X}$ & $\mathrm{X}$ & & \\
\hline Mississippi River near St. Francisville, La. & LM 266.4 & $\mathrm{X}$ & $\mathrm{X}$ & $\mathrm{X}$ & $\mathrm{X}$ & $\mathrm{X}$ \\
\hline Mississippi River below Belle Chasse, La. & LM 73.1 & $\mathrm{X}$ & $\mathrm{X}$ & $\mathrm{X}$ & $\mathrm{X}$ & $\mathrm{X}$ \\
\hline
\end{tabular}

${ }^{1} \mathrm{UM}$, Upper Mississippi River miles measured upriver of confluence with Ohio River.

IL, Illinois River miles measured upriver of confluence with Mississippi River (UM 218.0).

MO, Missouri River miles measured upriver of confluence with Mississippi River (UM 195.3).

$\mathrm{OH}$, Ohio River miles measured downriver of Pittsburgh, PA. Ohio-Mississippi River confluence is at Ohio River Mile 981.5 and Lower Mississippi River mile 953.8.

WA, Wabash River miles measured upriver of confluence with Ohio River (OH 848.0).

CU, Cumberland River miles measured upriver of confluence with Ohio River (OH 923.2).

TE, Tennessee River miles measured upriver of confluence with Ohio River ( $\mathrm{OH} 935.5)$.

LM, Lower Mississippi River miles measured upriver of Head of Passes, La.

WH, White River miles measured upriver of confluence with Mississippi River (LM 598.9).

AR, Arkansas River miles measured upriver of confluence with Mississippi River (LM 581.5).

YZ, Yazoo River miles measured upriver of confluence with Mississippi River (LM 437.2).

OR, Old River Outflow Channel miles measured downriver of the Old River control structure (LM 314.5). 
Table 2. Mississippi River suspended-sediment concentration (smaller than 63 micrometer), water discharge, and organic-carbon content.

[mg/L, milligrams per liter; $\mathrm{m}^{3} / \mathrm{sec}$, cubic meters per second; Suspended-sediment and discharge data from Moody and Meade, 1992 and 1993]

\begin{tabular}{|c|c|c|c|c|c|}
\hline Date & River & Sample site & $\begin{array}{c}\text { Suspended- } \\
\text { sediment } \\
\text { concentration } \\
\text { (mg/L) }\end{array}$ & $\begin{array}{c}\text { Water } \\
\text { discharge } \\
\left(\mathrm{m}^{3} / \mathrm{s}\right)\end{array}$ & $\begin{array}{c}\text { Organic- } \\
\text { carbon } \\
\text { content } \\
\text { (percent) }\end{array}$ \\
\hline \multicolumn{6}{|c|}{ MAY-JUNE 1988} \\
\hline $5-17$ & Mississippi River & near Winfield, Mo. & 34 & 1,700 & 6.70 \\
\hline $5-16$ & Illinois River & below Meredosia, Ill. & 58 & 330 & 4.28 \\
\hline $5-20$ & Mississippi River & at St. Louis, Mo. & 66 & 3,300 & 3.61 \\
\hline $5-22$ & Mississippi River & at Thebes, Ill. & 74 & 3,600 & 3.81 \\
\hline $5-23$ & Ohio River & at Olmsted, Ill. & 32 & 3,200 & 3.84 \\
\hline $5-24$ & Mississippi River & below Hickman, Ky. & 60 & 6,800 & 3.47 \\
\hline $5-29$ & White River & at Mile 11.5, Ark. & 96 & 440 & 2.02 \\
\hline $5-30$ & Mississippi River & above Arkansas City, Ark. & 87 & 8,200 & 3.37 \\
\hline $6-01$ & Yazoo River & at Mile 10.0, Miss. & 72 & 70 & 1.66 \\
\hline $6-02$ & Mississippi River & below Vicksburg, Miss. & 80 & 8,000 & 3.79 \\
\hline $6-04$ & Old River Outflow Channel & near Knox Landing, La. & 74 & 2,200 & 3.00 \\
\hline $6-05$ & Mississippi River & near St. Francisville, La. & 214 & 5,700 & 1.54 \\
\hline $6-07$ & Mississippi River & below Belle Chasse, La. & 18 & 5,600 & 3.74 \\
\hline \multicolumn{6}{|c|}{ MARCH-APRIL 1989} \\
\hline $3-16$ & Ohio River & at Olmsted, Ill. & 152 & 20,400 & 2.27 \\
\hline $3-17$ & Mississippi River & below Hickman, Ky. & 133 & 24,700 & 2.47 \\
\hline $3-19$ & Mississippi River & below Fulton, Tenn. & 138 & 24,800 & 2.36 \\
\hline $3-21$ & Mississippi River & at Helena, Ark. & 133 & 25,900 & 2.26 \\
\hline $3-22$ & White River & at Mile 11.5, Ark. & 44 & 1,500 & 1.95 \\
\hline $3-23$ & Arkansas River & at Pendleton, Ark. & 41 & 1,900 & 3.08 \\
\hline $3-24$ & Mississippi River & above Arkansas City, Ark. & 124 & 26,800 & 2.16 \\
\hline $3-26$ & Yazoo River & below Steele Bayou, Miss. & 150 & 1,500 & 1.42 \\
\hline $3-27$ & Mississippi River & below Vicksburg, Miss. & 122 & 26,600 & 2.11 \\
\hline $3-29$ & Old River Outflow Channel & near Knox Landing, La. & 162 & 6,160 & 1.65 \\
\hline $3-30$ & Mississippi River & near St. Francisville, La. & 116 & 23,100 & 2.06 \\
\hline $4-01$ & Mississippi River & below Belle Chasse, La. & 146 & 22,500 & 1.71 \\
\hline
\end{tabular}


Table 2. Mississippi River suspended-sediment concentration (smaller than 63 micrometer), water discharge, and organic-carbon content.-Continued

\begin{tabular}{|c|c|c|c|c|c|}
\hline Date & River & Sample site & $\begin{array}{c}\text { Suspended- } \\
\text { sediment } \\
\text { concentration } \\
\text { (mg/L) }\end{array}$ & $\begin{array}{c}\text { Water } \\
\text { discharge } \\
\left(\mathrm{m}^{3} / \mathbf{s}\right)\end{array}$ & $\begin{array}{c}\text { Organic- } \\
\text { carbon } \\
\text { content } \\
\text { (percent) }\end{array}$ \\
\hline \multicolumn{6}{|c|}{ JUNE 1989} \\
\hline $6-05$ & Mississippi River & near Winfield, Mo. & 70 & 2,320 & 4.09 \\
\hline $6-04$ & Illinois River & at Hardin, Ill. & 708 & 780 & 2.20 \\
\hline $6-08$ & Mississippi River & at St. Louis, Mo. & 122 & 4,760 & 3.14 \\
\hline $6-10$ & Mississippi River & at Thebes, Ill. & 117 & 5,230 & 3.19 \\
\hline $6-11$ & Ohio River & at Olmsted, Ill. & 115 & 8,760 & 2.46 \\
\hline $6-12$ & Mississippi River & below Hickman, Ky. & 130 & 14,100 & 2.50 \\
\hline $6-18$ & White River & at Mile 11.5, Ark. & 92 & 770 & 1.81 \\
\hline $6-19$ & Arkansas River & at Pendleton, Ark. & 68 & 3,600 & 2.64 \\
\hline $6-20$ & Mississippi River & above Arkansas City, Ark. & 170 & 23,300 & 2.14 \\
\hline $6-22$ & Yazoo River & below Steele Bayou, Miss. & 272 & 1,070 & 1.20 \\
\hline $6-23$ & Mississippi River & below Vicksburg, Miss. & 153 & 24,800 & 1.98 \\
\hline $6-25$ & Old River Outflow Channel & near Knox Landing, La. & 160 & 4,890 & 2.18 \\
\hline $6-26$ & Mississippi River & near St. Francisville, La. & 154 & 19,000 & 1.81 \\
\hline $6-28$ & Mississippi River & below Belle Chasse, La. & 170 & 20,100 & 1.72 \\
\hline $3-03$ & Ohio River & at Olmsted, Ill. & 144 & 16,100 & 2.41 \\
\hline $3-04$ & Mississippi River & below Hickman, Ky. & 158 & 2,100 & 2.19 \\
\hline $3-05$ & Mississippi River & below Fulton, Tenn. & 141 & 22,800 & 2.12 \\
\hline $3-07$ & Mississippi River & at Helena, Ark. & 146 & 23,300 & 2.43 \\
\hline $3-08$ & Mississippi River & above Arkansas City, Ark. & 126 & 33,200 & 2.11 \\
\hline $3-10$ & Mississippi River & below Vicksburg, Miss. & 126 & 34,100 & 1.95 \\
\hline $3-12$ & Mississippi River & near St. Francisville, La. & 98 & 26,300 & 2.02 \\
\hline $3-14$ & Mississippi River & below Belle Chasse, La. & 140 & 26,700 & 1.75 \\
\hline \multicolumn{6}{|c|}{ MAY-JUNE 1990} \\
\hline $6-07$ & Illinois River & at Valley City, Ill. & 98 & 1,230 & 2.98 \\
\hline $6-11$ & Mississippi River & below Grafton, Ill. & 464 & 5,040 & 2.24 \\
\hline $6-13$ & Mississippi River & at Thebes, Ill. & 1115 & 12,600 & 1.83 \\
\hline $6-14$ & Ohio River & at Olmsted, Ill. & 177 & 9,550 & 1.87 \\
\hline
\end{tabular}


Table 2. Mississippi River suspended-sediment concentration (smaller than 63 micrometer), water discharge, and organic-carbon content.-Continued

\begin{tabular}{rllccc}
\hline & & & $\begin{array}{c}\text { Suspended- } \\
\text { sediment } \\
\text { concentration } \\
(\mathbf{m g} / \mathbf{L})\end{array}$ & $\begin{array}{c}\text { Water } \\
\text { discharge } \\
\left(\mathbf{m}^{3} / \mathbf{s}\right)\end{array}$ & $\begin{array}{c}\text { Organic- } \\
\text { carbon } \\
\text { content } \\
\text { (percent) }\end{array}$ \\
\hline Date & \multicolumn{1}{c}{ River } & \multicolumn{1}{c}{ Sample site } & MAY-JUNE 1990_-Continued \\
$6-18$ & Mississippi River & below Memphis, Tenn. & 432 & 20,800 & 2.06 \\
$6-20$ & Mississippi River & below Arkansas City, Ark. & 334 & 25,500 & 1.92 \\
$6-23$ & Mississippi River & below Vicksburg, Miss. & 273 & 27,300 & 2.00 \\
$6-25$ & Mississippi River & near St. Francisville, La. & 184 & 23,200 & 1.83 \\
$6-27$ & Mississippi River & below Belle Chasse, La. & 183 & 23,300 & 2.03 \\
\hline
\end{tabular}

\section{Sample preparation}

Ultra-high-purity distilled-in-glass (Burdick and Jackson $\mathrm{GC}^{2}$ ) solvents were used. All glassware was baked 8 hours at $340^{\circ} \mathrm{C}$ prior to use. The suspended sediment (smaller than 63 micrometers) was air-dried at about $23^{\circ} \mathrm{C}$, ground in a glass mortar, weighed, and mixed well; a portion was taken for organic-carbon analysis. From the remaining sediment, about $15 \mathrm{~g}$ (from the first cruise; larger amounts when possible from later cruises) was weighed into a $150-\mathrm{mL}$ centrifuge bottle and spiked with 10 microliters of $40 \mathrm{ng} /$ microliter 4,4'-dibromooctafluorobiphenyl and $128 \mathrm{ng} /$ microliter of terbuthylazine. The sample was tumbled for 15 minutes to equilibrate the spiked compounds with the sediment. The sample was then extracted twice with $20 \mathrm{~mL}$ acetone and once with $5 \mathrm{~mL}$ hexane using a sonic probe (Tekmar), pulsed for 3 minutes at 60 -percent duty cycle, 40-percent output control, centrifuged at 1,500 revolutions per minute for 10 minutes, and the organic solvent was decanted. The extracts were combined, dried over anhydrous $\mathrm{Na}_{2} \mathrm{SO}_{4}$, and concentrated to less than $10 \mathrm{~mL}$ in a Kuderna-Danish apparatus. Under a gentle stream of dry $\mathrm{N} 2$, the sample extract was reduced to about $0.5 \mathrm{~mL}$. The extract was fractionated either on $3 \mathrm{~g}$ of neutral alumina (BioRad AG-7) with 10-mL fractions of (a)hexane; (b)benzene; (c)dichloromethane; (d) 1:1 dichloromethane:methanol; and (e)methanol, or on $5 \mathrm{~g}$ of 2 percent deactivated florisil with 100-mL fractions of (aa)hexane; (bb) 1:1 hexane:ethyl ether; (cc)dichloromethane; (dd)ethyl acetate. The (a) and (b) or (aa), (bb), and (cc) fractions were combined and concentrated to less than $0.5 \mathrm{~mL}$ as before. The (d), (e), and (dd) fractions were stored for future analysis. All concentrated extracts were stored in a freezer until analyzed.

\section{Sample analysis}

The combined fractions were spiked with injection standards, decafluorobiphenyl and d-10 phenanthrene, and analyzed in triplicate by gas chromatography/negative chemi- cal ionization/mass spectrometry (GC/NCI/MS). The extracts were injected at $280^{\circ} \mathrm{C}$ on a $30-\mathrm{m}, 0.25-\mathrm{mm}$ inside-diameter, 0.25 -micron Rtx-5 Restec GC column, at $50 \mathrm{oC}$ for $1 \mathrm{~min}$ ute, ramped to $300^{\circ} \mathrm{C}$ at $10^{\circ} \mathrm{C} / \mathrm{min}$ and held for 12 minutes. Electron-capture negative chemical ionization was achieved with ultra-high-purity methane reagent gas at 0.30 Torr in the ion source at $100^{\circ} \mathrm{C}$, with a filament emission current of 0.25 microamperes and electron energy of 100 electron volts. The Finnigan MAT TSQ-46 mass spectrometer scanned the first quadrupole from 50 to 600 daltons in 1 second, with the electron multiplier at 1,000 volts.

The base peak in the negative molecular-ion cluster of each selected compound was used for quantitation, based on the base peak of the surrogate internal standard, 4,4'-dibromooctafluorobiphenyl. A six-point calibration curve was generated for each selected compound. Calibration curves for the reference standard solutions ranging up to four orders of magnitude had correlation coefficients ranging from 0.988 to 0.998 , and averaged 0.995 for the selected organic compounds. DDT and its degradation products, DDE and DDD, were not quantitated using this protocol because of their low, nonspecific response to NCI.

With time, the instrument loses sensitivity due to contamination of the ion source. Contamination occurs from the chemical ionization, but also from the complex matrix of the samples. The ion volume in the ion source was replaced often to compensate for this problem. Because the response is dependent upon reagent gas pressure, fluctuations in the reagent gas pressure also can cause variations in the data. Because there could be instrumental reasons for variation of the data, especially nondetected values, samples were analyzed at least twice-more if a substantial loss in sensitivity may have occurred.

The instrumental analytical detection limit for the selected hydrophobic, anthropogenic organic compounds per 1-microliter injection of standard solution are shown in table 3 in nanograms. This value represents approximately $0.05 \mathrm{ng} / \mathrm{g}$ for penta- and hexachlorobenzene for a 100-microliter extract of a 20-g sample. Higher detection limits exist, especially for 
pentachlorophenol and chlorthalonil, due to their polarity. The selected compounds were below detection limits in all blanks analyzed.

Because variation in the extent of halogenation causes variations in the NCI response, the polychlorinated biphenyl quantitation was based on a reference standard compound with the same level of chlorination (Erhardt-Zabik and others, 1990). One isomer each of penta-, hexa-, hepta-, and octachlorobiphenyl was arbitrarily chosen as the quantitation reference standard. As discussed in American Society for Testing and Materials Special Technical Publication 976 (Alford-Stevens and Budde, 1988), the magnitude of the inherent error due to this quantitation approach is unknown. No attempt was made to match the isomer distribution pattern to a single technical Arochlor mixture, new or weathered.

Recovery studies require a similar sample matrix devoid of the compounds of interest. Noncontaminated suspended sediment was not available, so a well-mixed composite of excess sediment from several sites was used for recovery studies. An unspiked composite sample and triplicates spiked with the target compounds at $20 \mathrm{ng} / \mathrm{g}$ were carried through the entire extraction and analysis. The background levels from the unspiked composite sample were subtracted to produce the percent recovery for the target compounds shown in table 4, along with the percent relative standard deviation for the triplicate extractions. Chlorothalonil recovery was only 1 percent.

Table 3. Instrumental analytical detection limit for 1 microliter of standard solution.

\begin{tabular}{lc}
\hline \multicolumn{1}{c}{ Compound } & $\begin{array}{c}\text { Detection limit, } \\
\text { in nanograms }\end{array}$ \\
\hline Pentachlorobenzene & 0.01 \\
Hexachlorobenzene & 0.01 \\
Pentachloroanisole & 0.01 \\
Chlorothalonil & 1.00 \\
& \\
Pentachlorophenol & 10.00 \\
Dachthal & 0.01 \\
Chlordane, cis- + trans- & 0.10 \\
Nonachlor, trans- & 0.10 \\
& \\
Pentachlorobiphenyls & 0.50 \\
Hexachlorobiphenyls & 0.50 \\
Heptachlorobiphenyls & 0.05 \\
Octachlorobiphenyls & 0.05 \\
\hline
\end{tabular}

Seventeen June 1989 and eight February-March 1990 extracts were reanalyzed for EPA priority pollutants by GC/MS at the U.S. Geological Survey National Water Quality Laboratory in Denver using standard protocol (Wershaw and others, 1983). The sample extracts also were screened semiquantitatively for some organochlorines, triazines, and carbamates. Some of these semiquantitative compounds, such as atrazine, are water soluble and would not be expected to associate with the suspended sediment. Quantitation was based on the internal injection standard, d-10 phenanthrene.

\section{Organic Contaminant Data}

The mass in nanograms of each of the selected hydrophobic halogenated compounds in each sample was determined by duplicate or triplicate analysis of the same extract. In tables 5-9, the original sample weight in grams is shown along with the nanograms of target compound from the reported mass of sample. The data are not corrected for recovery. The detection limit in $\mathrm{ng} / \mathrm{g}$ is dependent on sample size. By reporting the data in mass, the detection limits are the same for all samples. ND indicates the constituent was not detected. Sample sites are listed in downstream order, with the tributaries included. Not all sites were sampled each cruise, as noted in table 1. Further details on sampling sites may be found in reports by Moody and Meade (1992 and 1993).

Table 4. Percent recovery for triplicate samples spiked at 20 nanograms of target compound per gram suspended sediment.

$[\mathrm{RSD}=$ relative standard deviation $]$

\begin{tabular}{lcc}
\hline \multicolumn{1}{c}{ Compound } & $\begin{array}{c}\text { Percent } \\
\text { recovery }\end{array}$ & $\begin{array}{c}\text { Percent } \\
\text { RSD }\end{array}$ \\
\hline Pentachlorobenzene & 159 & 11 \\
Hexachlorobenzene & 136 & 13 \\
Pentachloroanisole & 168 & 5 \\
Chlorothalonil & 1 & 66 \\
Pentachlorophenol & 102 & 97 \\
Dachthal & 122 & 25 \\
Chlordane, cis- + trans- & 147 & 17 \\
Nonachlor, trans- & 107 & 11 \\
Pentachlorobiphenyls & 207 & 49 \\
Hexachlorobiphenyls & 139 & 93 \\
Heptachlorobiphenyls & 115 & 35 \\
Octachlorobiphenyls & 106 & 38 \\
\hline
\end{tabular}


Table 5. Halogenated organic compounds found in suspended-sediment samples collected during the May-June 1988 cruise.

[ND, not detected; --, no data; masses not corrected for recovery; all masses rounded to two significant figures]

\begin{tabular}{|c|c|c|c|c|c|}
\hline \multirow[b]{3}{*}{ Sampling site and sample weight } & \multirow[b]{3}{*}{ Compound } & \multicolumn{4}{|c|}{ Mass of compound, in nanograms } \\
\hline & & \multicolumn{3}{|c|}{ Replicate samples } & \multirow[b]{2}{*}{ Averag } \\
\hline & & A & B & C & \\
\hline \multirow{12}{*}{$\begin{array}{l}\text { Mississippi River near Winfield, Mo. } \\
\text { 12-gram sample }\end{array}$} & Pentachlorobenzene & 3.6 & 3.7 & -- & 3.6 \\
\hline & Hexachlorobenzene & 5.4 & 5.5 & -- & 5.4 \\
\hline & Pentachloroanisole & 35 & 32 & -- & 34 \\
\hline & Chlorothalonil & 4.3 & ND & -- & 4.3 \\
\hline & Pentachlorophenol & ND & ND & -- & ND \\
\hline & Dachthal & 21 & 13 & -- & 17 \\
\hline & Chlordane, cis- + trans- & 45 & 50 & -- & 48 \\
\hline & Nonachlor, trans- & 14 & 21 & -- & 18 \\
\hline & Pentachlorobiphenyls & 290 & 380 & -- & 340 \\
\hline & Hexachlorobiphenyls & 850 & 530 & -- & 690 \\
\hline & Heptachlorobiphenyls & 66 & 77 & -- & 72 \\
\hline & Octachlorobiphenyls & 14 & 11 & -- & 12 \\
\hline \multirow{12}{*}{$\begin{array}{l}\text { Illinois River below Meredosia, Ill., } \\
\text { 15-gram sample }\end{array}$} & Pentachlorobenzene & 5.8 & 3.5 & -- & 4.6 \\
\hline & Hexachlorobenzene & 6.5 & 6.3 & -- & 6.4 \\
\hline & Pentachloroanisole & 14 & 14 & -- & 14 \\
\hline & Chlorothalonil & 2.2 & ND & -- & 2.2 \\
\hline & Pentachlorophenol & ND & ND & -- & ND \\
\hline & Dachthal & 17 & 15 & -- & 16 \\
\hline & Chlordane, cis- + trans- & 160 & 180 & -- & 170 \\
\hline & Nonachlor, trans- & 40 & 41 & -- & 40 \\
\hline & Pentachlorobiphenyls & 700 & 600 & -- & 650 \\
\hline & Hexachlorobiphenyls & 1200 & 1200 & -- & 1200 \\
\hline & Heptachlorobiphenyls & 270 & 300 & -- & 280 \\
\hline & Octachlorobiphenyls & 72 & 18 & -- & 45 \\
\hline \multirow{12}{*}{$\begin{array}{l}\text { Missouri River at Hermann, Mo., } \\
\text { 15-gram sample }\end{array}$} & Pentachlorobenzene & 6.7 & ND & ND & 6.7 \\
\hline & Hexachlorobenzene & 4.2 & 2.2 & 2.7 & 3 \\
\hline & Pentachloroanisole & 9.6 & 3.6 & 2.9 & 5.4 \\
\hline & Chlorothalonil & 0.98 & 0.44 & ND & 0.71 \\
\hline & Pentachlorophenol & ND & 62 & ND & 62 \\
\hline & Dachthal & 1.6 & 1.5 & 1.1 & 1.4 \\
\hline & Chlordane, cis- + trans- & 68 & 62 & 54 & 61 \\
\hline & Nonachlor, trans- & 28 & 8 & 9.6 & 15 \\
\hline & Pentachlorobiphenyls & ND & ND & 260 & 260 \\
\hline & Hexachlorobiphenyls & 360 & 460 & 430 & 420 \\
\hline & Heptachlorobiphenyls & 22 & 34 & 39 & 32 \\
\hline & Octachlorobiphenyls & 10.3 & 8.9 & 5.2 & 8.1 \\
\hline
\end{tabular}


Table 5. Halogenated organic compounds found in suspended-sediment samples collected during the May-June 1988 cruise.Continued

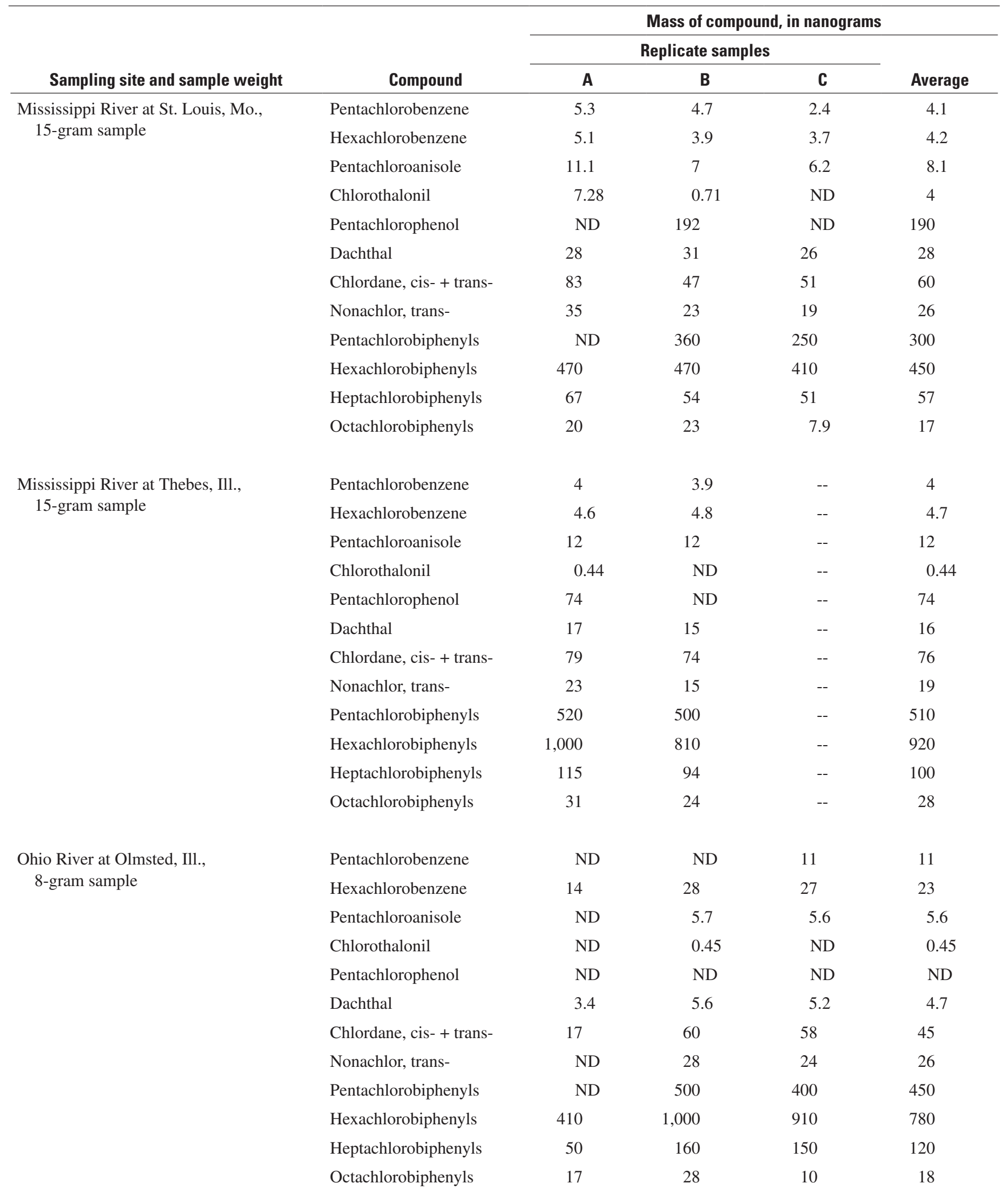


Table 5. Halogenated organic compounds found in suspended-sediment samples collected during the May-June 1988 cruise.Continued

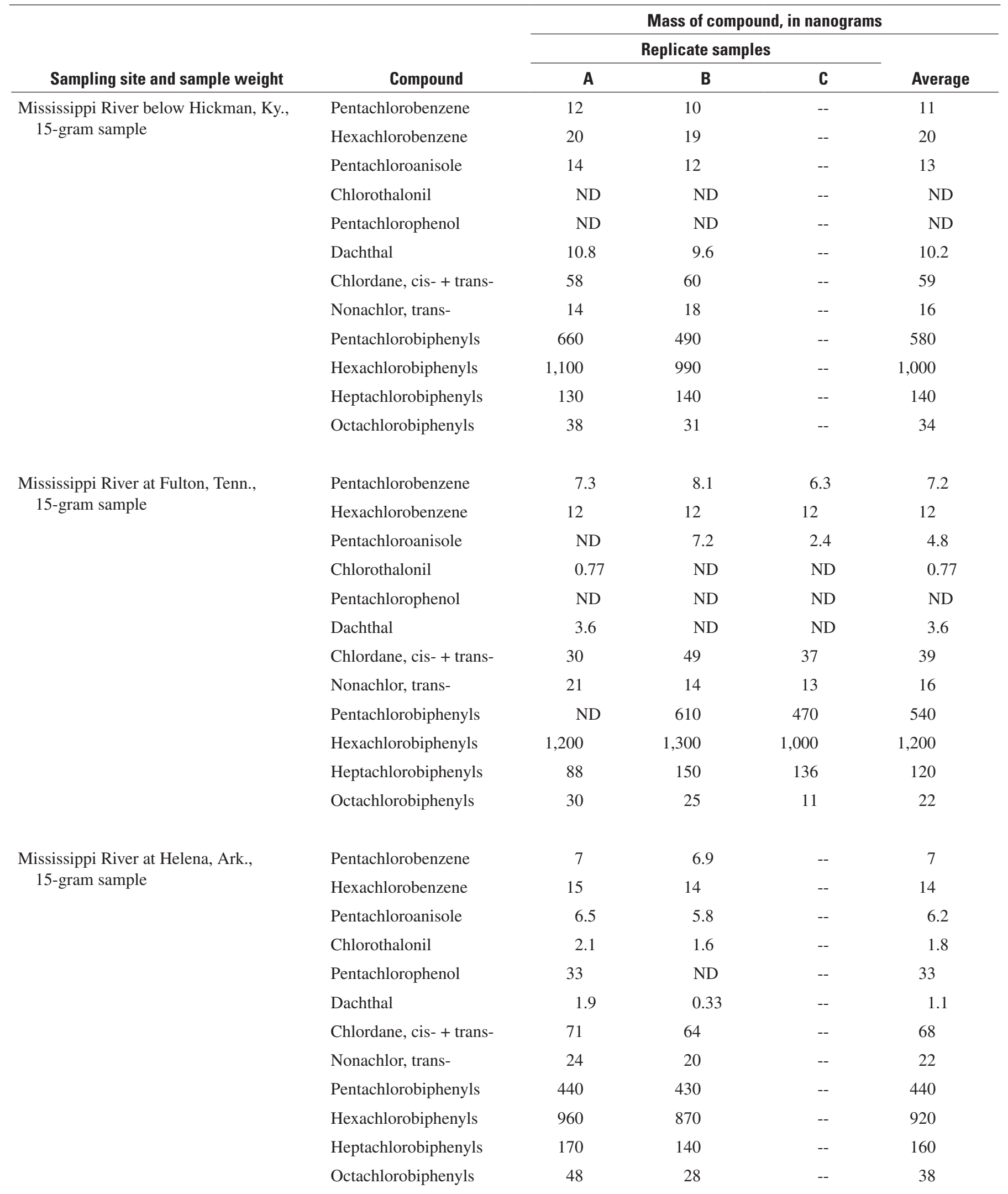


Table 5. Halogenated organic compounds found in suspended-sediment samples collected during the May-June 1988 cruise.Continued

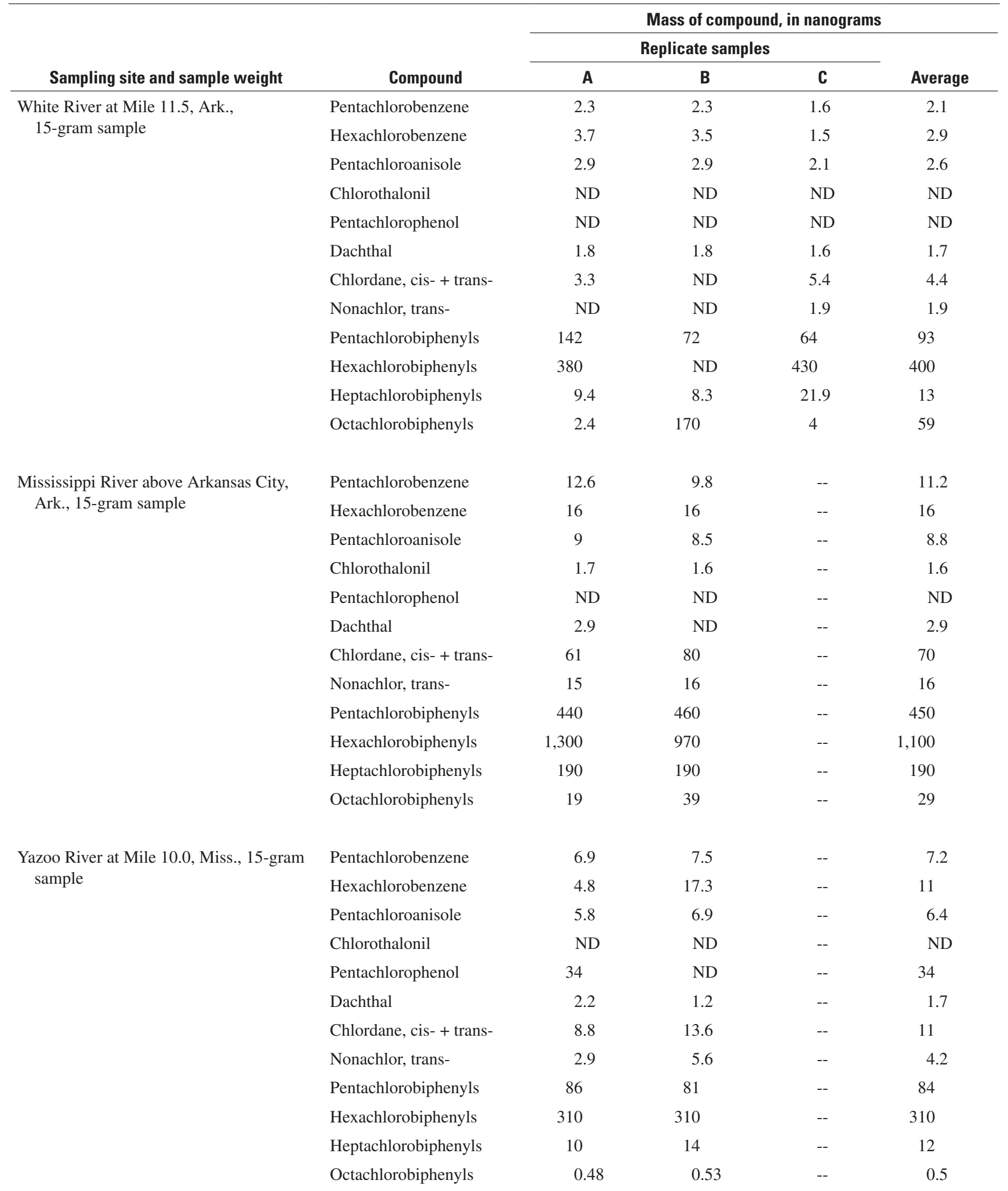


Table 5. Halogenated organic compounds found in suspended-sediment samples collected during the May-June 1988 cruise.Continued

\begin{tabular}{|c|c|c|c|c|c|}
\hline \multirow[b]{3}{*}{ Sampling site and sample weight } & \multirow[b]{3}{*}{ Compound } & \multicolumn{4}{|c|}{ Mass of compound, in nanograms } \\
\hline & & \multicolumn{3}{|c|}{ Replicate samples } & \multirow[b]{2}{*}{ Average } \\
\hline & & A & B & C & \\
\hline \multirow{7}{*}{$\begin{array}{l}\text { Mississippi River below Vicksburg, Miss., } \\
\text { 15-gram sample }\end{array}$} & Hexachlorobenzene & 30 & 32 & 27 & 30 \\
\hline & Pentachloroanisole & 12.6 & 8.4 & 6.5 & 9.2 \\
\hline & Pentachlorophenol & ND & ND & ND & ND \\
\hline & Dachthal & 8.8 & 6.5 & 5.4 & 6.9 \\
\hline & Chlordane, cis- + trans- & 84 & 65 & 53 & 67 \\
\hline & Nonachlor, trans- & 33.4 & 19.8 & 8.8 & 21 \\
\hline & Octachlorobiphenyls & 50 & 11 & 15 & 25 \\
\hline \multirow{6}{*}{$\begin{array}{l}\text { Old River Outflow Channel near Knox } \\
\text { Landing, La., 15-gram sample }\end{array}$} & Pentachlorobenzene & 6.6 & 12.1 & 9.6 & 9.4 \\
\hline & Hexachlorobenzene & 12 & 13 & 13 & 13 \\
\hline & Pentachloroanisole & 5.6 & 8.8 & 9.2 & 7.9 \\
\hline & Chlorothalonil & 1.3 & ND & 1.4 & 1.4 \\
\hline & Pentachlorophenol & ND & ND & ND & ND \\
\hline & Dachthal & 8.6 & 7.5 & 5.3 & 7.1 \\
\hline \multirow{12}{*}{$\begin{array}{l}\text { Mississippi River near St. Francisville, } \\
\text { La., 15-gram sample }\end{array}$} & Pentachlorobenzene & 6 & 5.1 & -- & 5.6 \\
\hline & Hexachlorobenzene & 14 & 13 & -- & 14 \\
\hline & Pentachloroanisole & 6.5 & 5.1 & -- & 5.8 \\
\hline & Chlorothalonil & 1.3 & 0.4 & -- & 0.85 \\
\hline & Pentachlorophenol & 250 & ND & -- & 250 \\
\hline & Dachthal & 3.5 & 2.5 & -- & 3 \\
\hline & Chlordane, cis- + trans- & 25 & 23 & -- & 24 \\
\hline & Nonachlor, trans- & 5.4 & 5.2 & -- & 5.3 \\
\hline & Pentachlorobiphenyls & 270 & 260 & -- & 260 \\
\hline & Hexachlorobiphenyls & 820 & 440 & -- & 630 \\
\hline & Heptachlorobiphenyls & 86 & 69 & -- & 78 \\
\hline & Octachlorobiphenyls & 10 & 8.3 & -- & 9.2 \\
\hline
\end{tabular}


Table 5. Halogenated organic compounds found in suspended-sediment samples collected during the May-June 1988 cruise.Continued

\begin{tabular}{llcccc}
\hline & & \multicolumn{3}{c}{ Mass of compound, in nanograms } \\
\cline { 3 - 5 } \multicolumn{1}{c}{ Sampling site and sample weight } & \multicolumn{1}{c}{ Compound } & A & B & C & Average \\
\cline { 3 - 5 } Mississippite River below Belle Chasse, La., & Pentachlorobenzene & 8.2 & 7.4 & -- & 7.8 \\
& Hexachlorobenzene & 39 & 36 & -- & 38 \\
& Pentachloroanisole & 7 & 6.5 & -- & 6.8 \\
& Chlorothalonil & 0.2 & ND & -- & 0.2 \\
& Pentachlorophenol & ND & ND & -- & ND \\
& Dachthal & 0.47 & ND & -- & 0.47 \\
& Chlordane, cis- + trans- & 66 & 44 & -- & 55 \\
& Nonachlor, trans- & 21.9 & 8.4 & -- & 15 \\
& Pentachlorobiphenyls & 290 & 290 & -- & 290 \\
& Hexachlorobiphenyls & 860 & 790 & -- & 820 \\
& Heptachlorobiphenyls & 120 & 95.4 & -- & 110 \\
& Octachlorobiphenyls & 42.7 & 1.3 & -- & 22 \\
\hline
\end{tabular}


Table 6. Halogenated organic compounds found in suspended-sediment samples collected during the March-April 1989 cruise.

[ND, not detected; --, no data; masses not corrected for recovery; all masses rounded to two significant figures]

\begin{tabular}{|c|c|c|c|c|c|}
\hline \multirow[b]{3}{*}{ Sampling site and sample weight } & \multirow[b]{3}{*}{ Compound } & \multicolumn{4}{|c|}{ Mass of compound, in nanograms } \\
\hline & & \multicolumn{3}{|c|}{ Replicate samples } & \multirow[b]{2}{*}{ Average } \\
\hline & & A & B & C & \\
\hline \multirow{12}{*}{$\begin{array}{l}\text { Mississippi River near Winfield, Mo., } \\
\text { 7.2-gram sample }\end{array}$} & Pentachlorobenzene & ND & 6.6 & 7.6 & 7.1 \\
\hline & Hexachlorobenzene & 7 & 11 & 8.5 & 8.8 \\
\hline & Pentachloroanisole & 66 & 48 & 46 & 53 \\
\hline & Chlorothalonil & 6.7 & 1.5 & 3.1 & 3.8 \\
\hline & Pentachlorophenol & 600 & 1,500 & 670 & 920 \\
\hline & Dachthal & 6.7 & 10.4 & 10.1 & 9.1 \\
\hline & Chlordane, cis- + trans- & ND & 49 & 37 & 43 \\
\hline & Nonachlor, trans- & ND & 79 & 38 & 58 \\
\hline & Pentachlorobiphenyls & 1,300 & 1,100 & 900 & 1,100 \\
\hline & Hexachlorobiphenyls & 1,900 & 2,200 & 1,300 & 1,800 \\
\hline & Heptachlorobiphenyls & 24 & 73 & 36 & 44 \\
\hline & Octachlorobiphenyls & ND & 20.4 & 1.6 & 11 \\
\hline \multirow{12}{*}{$\begin{array}{l}\text { Illinois River at Hardin, Ill., } \\
\text { 39.96-gram sample }\end{array}$} & Pentachlorobenzene & 15 & 9.4 & -- & 12 \\
\hline & Hexachlorobenzene & 14 & 9.1 & -- & 12 \\
\hline & Pentachloroanisole & 50 & 32 & -- & 41 \\
\hline & Chlorothalonil & 2.7 & 1.8 & -- & 2.2 \\
\hline & Pentachlorophenol & 890 & ND & -- & 890 \\
\hline & Dachthal & 17.2 & 8.4 & -- & 13 \\
\hline & Chlordane, cis- + trans- & 135 & 99 & -- & 120 \\
\hline & Nonachlor, trans- & 110 & ND & -- & 110 \\
\hline & Pentachlorobiphenyls & 1,600 & 770 & -- & 1,200 \\
\hline & Hexachlorobiphenyls & 4,200 & 2,800 & -- & 3,500 \\
\hline & Heptachlorobiphenyls & 340 & 120 & -- & 230 \\
\hline & Octachlorobiphenyls & 68 & 37 & -- & 52 \\
\hline \multirow{12}{*}{$\begin{array}{l}\text { Missouri River at Hermann, Mo., } \\
\text { 21.15-gram sample }\end{array}$} & Pentachlorobenzene & 5 & 5.8 & -- & 5.4 \\
\hline & Hexachlorobenzene & 5.3 & 4.6 & -- & 5 \\
\hline & Pentachloroanisole & 13 & 20 & -- & 16 \\
\hline & Chlorothalonil & 1.7 & 2.6 & -- & 2.2 \\
\hline & Pentachlorophenol & 750 & 950 & -- & 850 \\
\hline & Dachthal & 5.8 & 3.2 & -- & 4.5 \\
\hline & Chlordane, cis- + trans- & 30 & 18 & -- & 24 \\
\hline & Nonachlor, trans- & 57 & ND & -- & 57 \\
\hline & Pentachlorobiphenyls & 94 & ND & -- & 94 \\
\hline & Hexachlorobiphenyls & 270 & 620 & -- & 440 \\
\hline & Heptachlorobiphenyls & 20 & 20 & -- & 20 \\
\hline & Octachlorobiphenyls & ND & ND & -- & $\mathrm{ND}$ \\
\hline
\end{tabular}


Table 6. Halogenated organic compounds found in suspended-sediment samples collected during the March-April 1989 cruise.Continued

\begin{tabular}{|c|c|c|c|c|c|}
\hline \multirow[b]{3}{*}{ Sampling site and sample weight } & \multirow[b]{3}{*}{ Compound } & \multicolumn{4}{|c|}{ Mass of compound, in nanograms } \\
\hline & & \multicolumn{3}{|c|}{ Replicate samples } & \multirow[b]{2}{*}{ Average } \\
\hline & & A & B & C & \\
\hline \multirow{7}{*}{$\begin{array}{l}\text { Mississippi River at St. Louis, Mo., } \\
\text { 20.80-gram sample }\end{array}$} & Hexachlorobenzene & 8.1 & 4.5 & -- & 6.3 \\
\hline & Pentachloroanisole & 22 & 27 & -- & 24 \\
\hline & Pentachlorophenol & ND & 1,400 & -- & 1,400 \\
\hline & Dachthal & 10.8 & 5.2 & -- & 8 \\
\hline & Chlordane, cis- + trans- & 53 & 51 & -- & 52 \\
\hline & Nonachlor, trans- & 32 & 108 & -- & 70 \\
\hline & Octachlorobiphenyls & 9.8 & 9 & -- & 9.4 \\
\hline \multirow{6}{*}{$\begin{array}{l}\text { Mississippi River at Thebes, Ill., } \\
\text { 24.81-gram sample }\end{array}$} & Pentachlorobenzene & 12.3 & 3.5 & -- & 7.9 \\
\hline & Hexachlorobenzene & 8.2 & 6.4 & -- & 7.3 \\
\hline & Pentachloroanisole & 21 & 47 & -- & 34 \\
\hline & Chlorothalonil & 7 & 3.3 & -- & 5.2 \\
\hline & Pentachlorophenol & ND & 540 & -- & 540 \\
\hline & Dachthal & 9.9 & 4.1 & -- & 7 \\
\hline \multirow{12}{*}{$\begin{array}{l}\text { Ohio River at Olmsted, Ill., } \\
\text { 39.97-gram sample }\end{array}$} & Pentachlorobenzene & 35 & 26 & -- & 30 \\
\hline & Hexachlorobenzene & 73 & 70 & -- & 72 \\
\hline & Pentachloroanisole & 109 & 98 & -- & 104 \\
\hline & Chlorothalonil & ND & 2.7 & -- & 2.7 \\
\hline & Pentachlorophenol & 760 & ND & -- & 760 \\
\hline & Dachthal & 9.7 & 7 & -- & 800 \\
\hline & Chlordane, cis- + trans- & 108 & 98 & -- & 100 \\
\hline & Nonachlor, trans- & 150 & 260 & -- & 200 \\
\hline & Pentachlorobiphenyls & 580 & 860 & -- & 720 \\
\hline & Hexachlorobiphenyls & 4,400 & 4,800 & -- & 4,600 \\
\hline & Heptachlorobiphenyls & 200 & 230 & -- & 220 \\
\hline & Octachlorobiphenyls & 44 & 80 & -- & 62 \\
\hline
\end{tabular}


Table 6. Halogenated organic compounds found in suspended-sediment samples collected during the March-April 1989 cruise.Continued

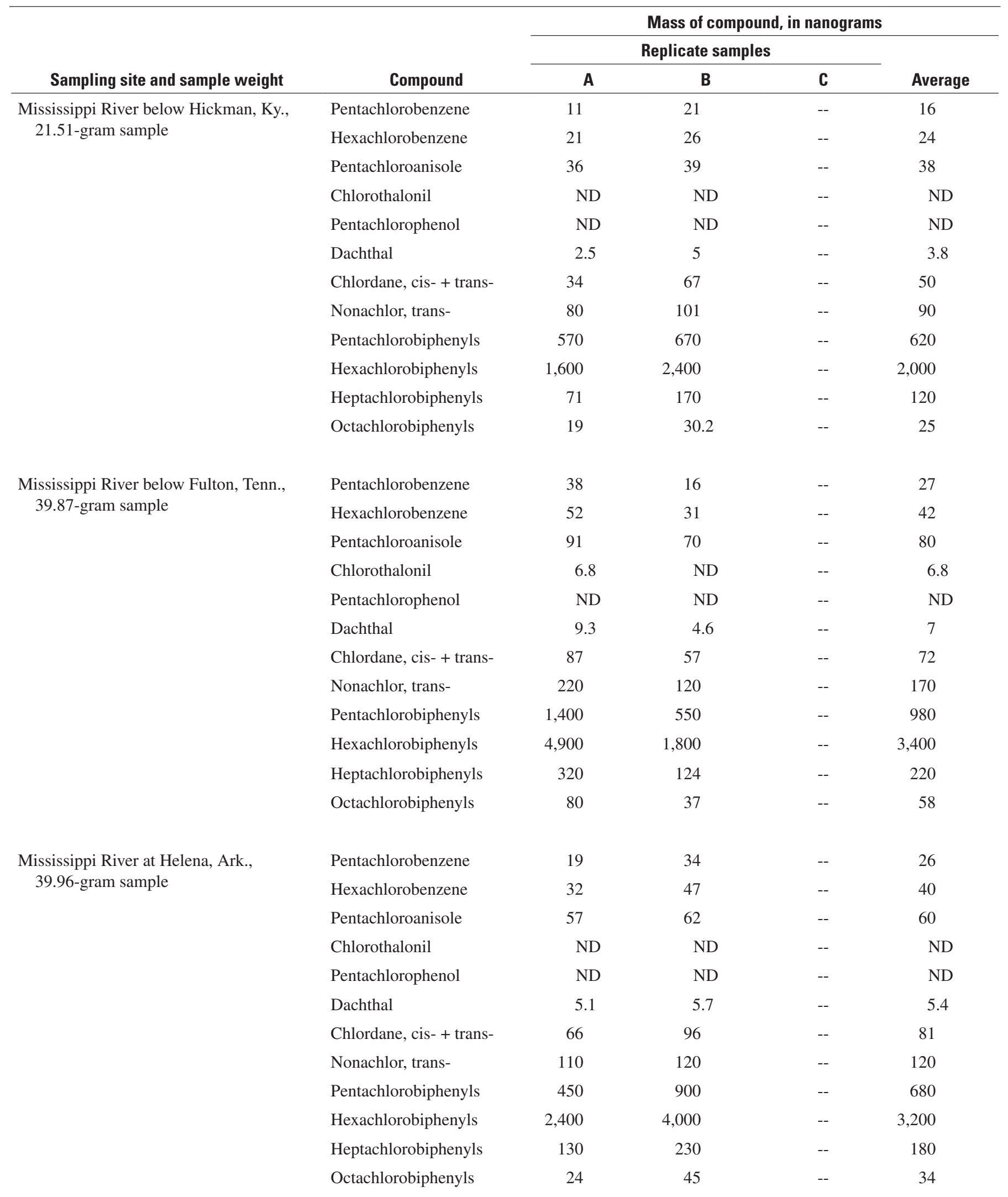


Table 6. Halogenated organic compounds found in suspended-sediment samples collected during the March-April 1989 cruise.Continued

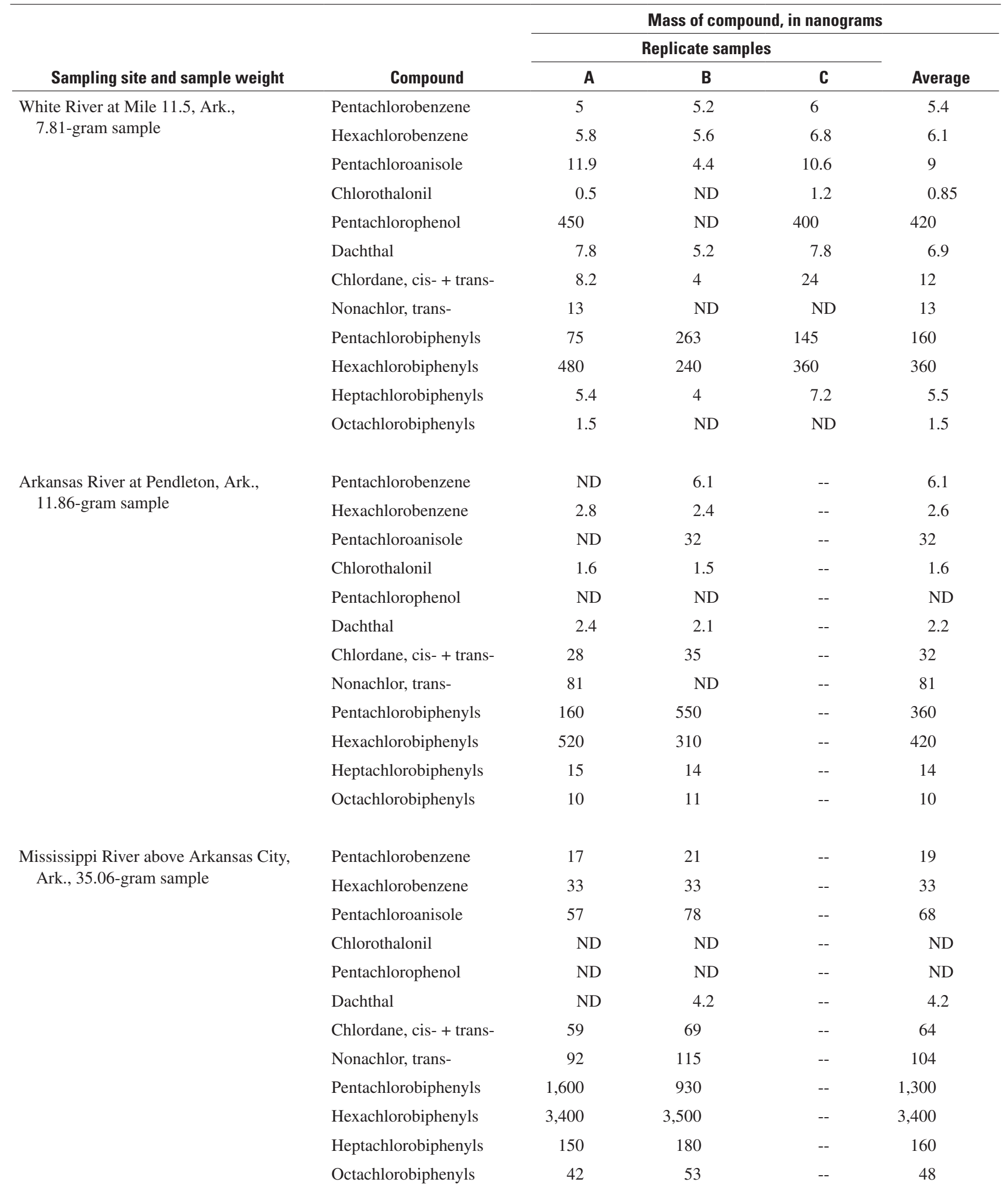


Table 6. Halogenated organic compounds found in suspended-sediment samples collected during the March-April 1989 cruise.Continued

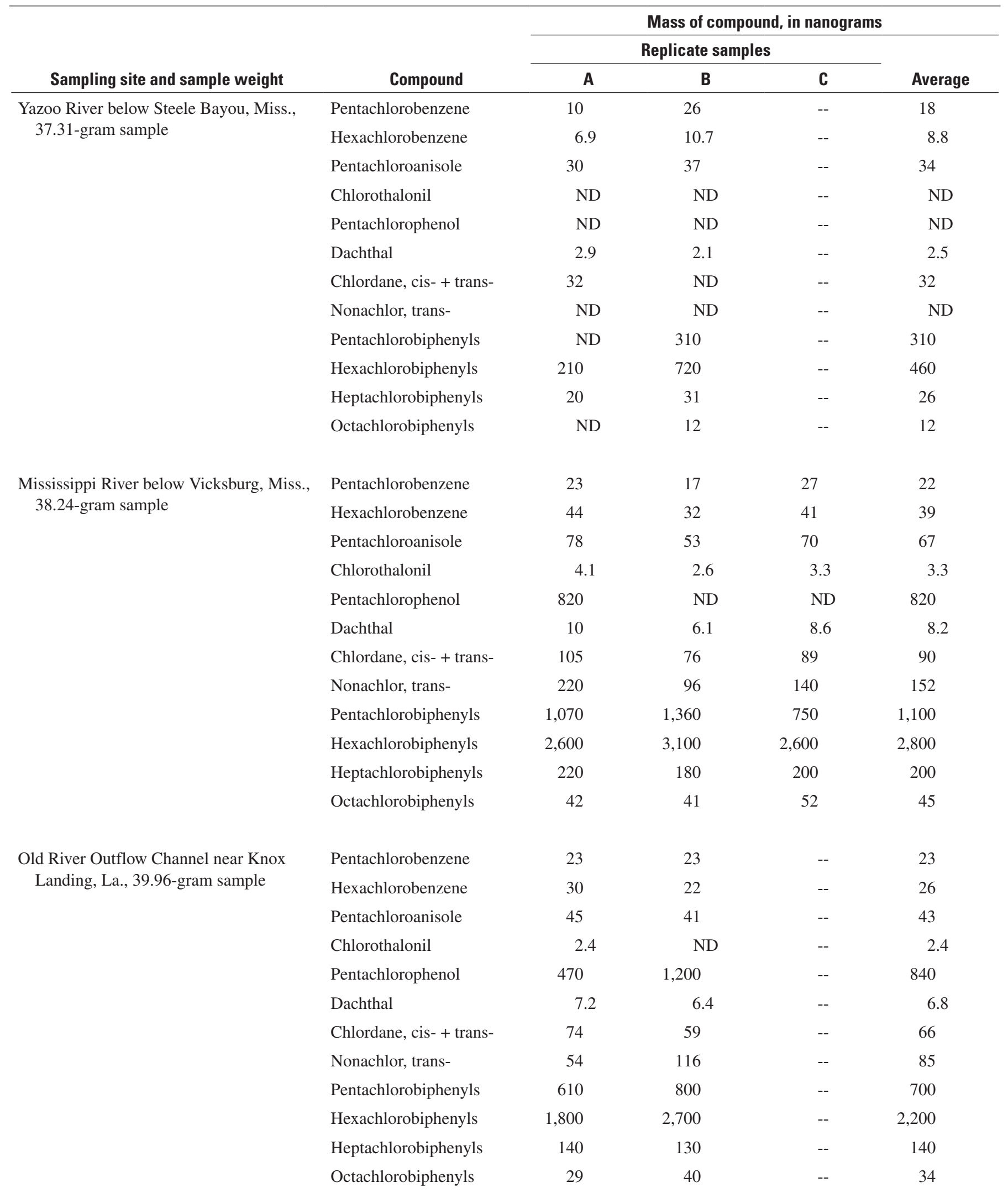


Table 6. Halogenated organic compounds found in suspended-sediment samples collected during the March-April 1989 cruise.Continued

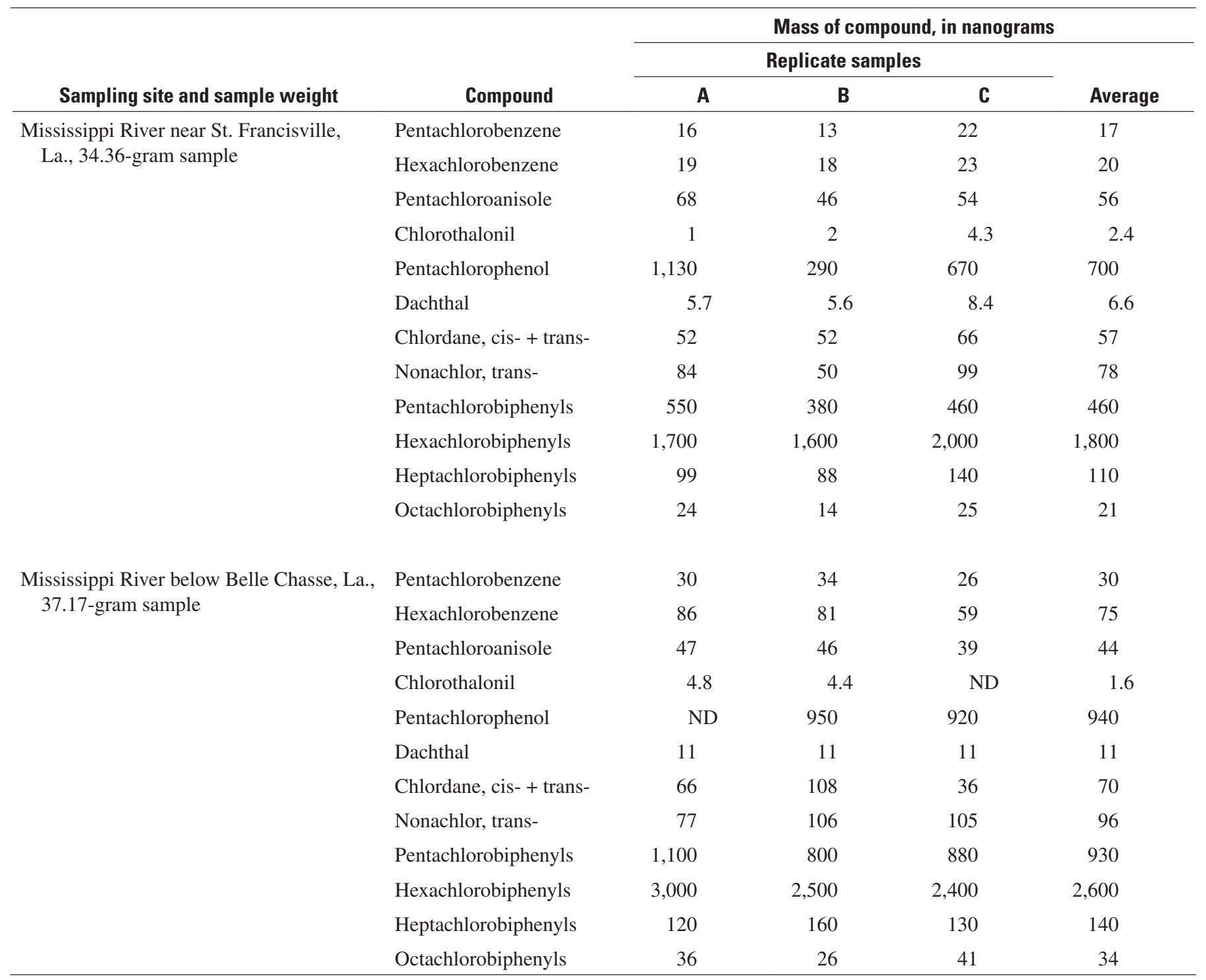


Table 7. Halogenated organic compounds found in suspended-sediment samples collected during the June 1989 cruise.

[ND, not detected; --, no data; masses not corrected for recovery; all masses rounded to two significant figures]

\begin{tabular}{|c|c|c|c|c|c|c|c|}
\hline \multirow[b]{3}{*}{ Sampling site and sample weight } & \multirow[b]{3}{*}{ Compound } & \multicolumn{6}{|c|}{ Mass of compound, in nanograms } \\
\hline & & \multicolumn{5}{|c|}{ Replicate samples } & \multirow[b]{2}{*}{ Average } \\
\hline & & A & B & C & D & $\mathbf{E}$ & \\
\hline \multirow{12}{*}{$\begin{array}{l}\text { Mississippi River near Winfield, Mo., } \\
\text { 19.90-gram sample }\end{array}$} & Pentachlorobenzene & 1 & ND & -- & -- & -- & 1 \\
\hline & Hexachlorobenzene & 3 & 2.1 & -- & -- & -- & 2.6 \\
\hline & Pentachloroanisole & ND & ND & -- & -- & -- & ND \\
\hline & Chlorothalonil & ND & ND & -- & -- & -- & ND \\
\hline & Pentachlorophenol & ND & ND & -- & -- & -- & ND \\
\hline & Dachthal & 7 & 4 & -- & -- & -- & 5.5 \\
\hline & Chlordane, cis- + trans- & 13 & $\mathrm{ND}$ & -- & -- & -- & 13 \\
\hline & Nonachlor, trans- & ND & ND & -- & -- & -- & ND \\
\hline & Pentachlorobiphenyls & 540 & 260 & -- & -- & -- & 400 \\
\hline & Hexachlorobiphenyls & 1,400 & 510 & -- & -- & -- & 960 \\
\hline & Heptachlorobiphenyls & 20.7 & 6.9 & -- & -- & -- & 14 \\
\hline & Octachlorobiphenyls & $\mathrm{ND}$ & $\mathrm{ND}$ & -- & -- & -- & ND \\
\hline \multirow{12}{*}{$\begin{array}{l}\text { Illinois River at Hardin, Ill., } \\
\text { 39.74-gram sample }\end{array}$} & Pentachlorobenzene & 18 & 27 & -- & -- & -- & 22 \\
\hline & Hexachlorobenzene & ND & 3.3 & -- & -- & -- & 303 \\
\hline & Pentachloroanisole & ND & $\mathrm{ND}$ & -- & -- & -- & ND \\
\hline & Chlorothalonil & ND & ND & -- & -- & -- & ND \\
\hline & Pentachlorophenol & ND & ND & -- & -- & -- & ND \\
\hline & Dachthal & 12 & 22 & -- & -- & -- & 17 \\
\hline & Chlordane, cis- + trans- & 21 & 129 & -- & -- & -- & 75 \\
\hline & Nonachlor, trans- & ND & 150 & -- & -- & -- & 150 \\
\hline & Pentachlorobiphenyls & 140 & 1,300 & -- & -- & -- & 720 \\
\hline & Hexachlorobiphenyls & 970 & 3,400 & -- & -- & -- & 2,200 \\
\hline & Heptachlorobiphenyls & 31 & 180 & -- & -- & -- & 110 \\
\hline & Octachlorobiphenyls & ND & 30 & -- & -- & -- & 30 \\
\hline \multirow{12}{*}{$\begin{array}{l}\text { Missouri River at Hermann, Mo., } \\
\text { 40.11-gram sample }\end{array}$} & Pentachlorobenzene & 3.6 & 1.3 & -- & -- & -- & 2.4 \\
\hline & Hexachlorobenzene & 4.9 & 2.6 & -- & -- & -- & 3.8 \\
\hline & Pentachloroanisole & 4.3 & 1.8 & -- & -- & -- & 3 \\
\hline & Chlorothalonil & 1.2 & ND & -- & -- & -- & 1.2 \\
\hline & Pentachlorophenol & 130 & ND & -- & -- & -- & 130 \\
\hline & Dachthal & 7.8 & 4.7 & -- & -- & -- & 6.2 \\
\hline & Chlordane, cis- + trans- & 31 & 18 & -- & -- & -- & 24 \\
\hline & Nonachlor, trans- & 41 & 15 & -- & -- & -- & 28 \\
\hline & Pentachlorobiphenyls & 47 & ND & -- & -- & -- & 47 \\
\hline & Hexachlorobiphenyls & 310 & 150 & -- & -- & -- & 230 \\
\hline & Heptachlorobiphenyls & 15.5 & 6.4 & -- & -- & -- & 11 \\
\hline & Octachlorobiphenyls & 1.4 & ND & -- & -- & -- & 1.4 \\
\hline
\end{tabular}


Table 7. Halogenated organic compounds found in suspended-sediment samples collected during the June 1989 cruise.-Continued

\begin{tabular}{|c|c|c|c|c|c|c|c|}
\hline \multirow[b]{3}{*}{ Sampling site and sample weight } & \multirow[b]{3}{*}{ Compound } & \multicolumn{6}{|c|}{ Mass of compound, in nanograms } \\
\hline & & \multicolumn{5}{|c|}{ Replicate samples } & \multirow[b]{2}{*}{ Average } \\
\hline & & A & B & C & D & $\mathbf{E}$ & \\
\hline \multirow{7}{*}{$\begin{array}{l}\text { Mississippi River at St. Louis, Mo., } \\
\text { 40.17-gram sample }\end{array}$} & Hexachlorobenzene & 7.2 & 7.5 & -- & -- & -- & 7.4 \\
\hline & Pentachloroanisole & 16 & 14 & -- & -- & -- & 15 \\
\hline & Pentachlorophenol & ND & ND & -- & -- & -- & ND \\
\hline & Dachthal & 15 & 14 & -- & -- & -- & 14 \\
\hline & Chlordane, cis- + trans- & 54 & 48 & -- & -- & -- & 51 \\
\hline & Nonachlor, trans- & 60 & 62 & -- & -- & -- & 61 \\
\hline & Octachlorobiphenyls & 9.9 & 11 & -- & -- & -- & 10 \\
\hline \multirow{6}{*}{$\begin{array}{l}\text { Mississippi River at Thebes, Ill., 30.99- } \\
\text { gram sample }\end{array}$} & Pentachlorobenzene & 5.4 & 5.7 & -- & -- & -- & 5.6 \\
\hline & Hexachlorobenzene & 5.1 & 5.5 & -- & -- & -- & 5.3 \\
\hline & Pentachloroanisole & 11 & 12 & -- & -- & -- & 12 \\
\hline & Chlorothalonil & ND & ND & -- & -- & -- & ND \\
\hline & Pentachlorophenol & ND & ND & -- & -- & -- & ND \\
\hline & Dachthal & 11 & 11 & -- & -- & -- & 11 \\
\hline \multirow{12}{*}{$\begin{array}{l}\text { Ohio River at Olmsted, Ill., } \\
\text { 40.21-gram sample }\end{array}$} & Pentachlorobenzene & 26 & 25 & -- & -- & -- & 26 \\
\hline & Hexachlorobenzene & 92 & 88 & -- & -- & -- & 90 \\
\hline & Pentachloroanisole & 41 & 37 & -- & -- & -- & 39 \\
\hline & Chlorothalonil & ND & ND & -- & -- & -- & ND \\
\hline & Pentachlorophenol & ND & ND & -- & -- & -- & ND \\
\hline & Dachthal & 22 & 22 & -- & -- & -- & 22 \\
\hline & Chlordane, cis- + trans- & 67 & 64 & -- & -- & -- & 66 \\
\hline & Nonachlor, trans- & 140 & 120 & -- & -- & -- & 130 \\
\hline & Pentachlorobiphenyls & 1,400 & 1,500 & -- & -- & -- & 1,400 \\
\hline & Hexachlorobiphenyls & 3,000 & 3,200 & -- & -- & -- & 3,100 \\
\hline & Heptachlorobiphenyls & 170 & 160 & -- & -- & -- & 160 \\
\hline & Octachlorobiphenyls & 33 & 26 & -- & -- & -- & 30 \\
\hline
\end{tabular}


Table 7. Halogenated organic compounds found in suspended-sediment samples collected during the June 1989 cruise.-Continued

\begin{tabular}{|c|c|c|c|c|c|c|c|}
\hline \multirow[b]{3}{*}{ Sampling site and sample weight } & \multirow[b]{3}{*}{ Compound } & \multicolumn{6}{|c|}{ Mass of compound, in nanograms } \\
\hline & & \multicolumn{5}{|c|}{ Replicate samples } & \multirow[b]{2}{*}{ Average } \\
\hline & & A & B & C & D & $\mathbf{E}$ & \\
\hline \multirow{12}{*}{$\begin{array}{l}\text { Mississippi River below Hickman, Ky., } \\
\text { 37.94-gram sample }\end{array}$} & Pentachlorobenzene & 15 & 15 & -- & -- & -- & 15 \\
\hline & Hexachlorobenzene & 57 & 56 & -- & -- & -- & 56 \\
\hline & Pentachloroanisole & 20 & 24 & -- & -- & -- & 22 \\
\hline & Chlorothalonil & ND & ND & -- & -- & -- & ND \\
\hline & Pentachlorophenol & ND & ND & -- & -- & -- & ND \\
\hline & Dachthal & 15 & 14 & -- & -- & -- & 14 \\
\hline & Chlordane, cis- + trans- & 64 & 71 & -- & -- & -- & 68 \\
\hline & Nonachlor, trans- & 91 & 101 & -- & -- & -- & 96 \\
\hline & Pentachlorobiphenyls & 1,300 & 1,400 & -- & -- & -- & 1,400 \\
\hline & Hexachlorobiphenyls & 2,600 & 2,700 & -- & -- & -- & 2,600 \\
\hline & Heptachlorobiphenyls & 146 & 144 & -- & -- & -- & 140 \\
\hline & Octachlorobiphenyls & 23 & 22 & -- & -- & -- & 22 \\
\hline \multirow{12}{*}{$\begin{array}{l}\text { Mississippi River at Fulton, Tenn., } \\
\text { 37.47-gram sample }\end{array}$} & Pentachlorobenzene & 16 & 18 & -- & -- & -- & 17 \\
\hline & Hexachlorobenzene & 40 & 41 & -- & -- & -- & 40 \\
\hline & Pentachloroanisole & 11 & 21 & -- & -- & -- & 14 \\
\hline & Chlorothalonil & ND & ND & -- & -- & -- & ND \\
\hline & Pentachlorophenol & ND & ND & -- & -- & -- & ND \\
\hline & Dachthal & 11 & 12 & -- & -- & -- & 12 \\
\hline & Chlordane, cis- + trans- & 40 & 42 & -- & -- & -- & 41 \\
\hline & Nonachlor, trans- & 45 & 44 & -- & -- & -- & 44 \\
\hline & Pentachlorobiphenyls & 670 & 820 & -- & -- & -- & 740 \\
\hline & Hexachlorobiphenyls & 2,200 & 2,100 & -- & -- & -- & 2,200 \\
\hline & Heptachlorobiphenyls & 96 & 107 & -- & -- & -- & 100 \\
\hline & Octachlorobiphenyls & 16 & 18 & -- & -- & -- & 17 \\
\hline \multirow{12}{*}{$\begin{array}{l}\text { Mississippi River at Helena, Ark., } \\
\text { 40.10-gram sample }\end{array}$} & Pentachlorobenzene & 15 & 16 & -- & -- & -- & 16 \\
\hline & Hexachlorobenzene & 34 & 34 & -- & -- & -- & 34 \\
\hline & Pentachloroanisole & 18 & 16 & -- & -- & -- & 17 \\
\hline & Chlorothalonil & ND & ND & -- & -- & -- & ND \\
\hline & Pentachlorophenol & ND & ND & -- & -- & -- & ND \\
\hline & Dachthal & 10.2 & 8.6 & -- & -- & -- & 9.4 \\
\hline & Chlordane, cis- + trans- & 34 & 36 & -- & -- & -- & 35 \\
\hline & Nonachlor, trans- & 41 & ND & -- & -- & -- & 41 \\
\hline & Pentachlorobiphenyls & 750 & 600 & -- & -- & -- & 680 \\
\hline & Hexachlorobiphenyls & 2,200 & 2,200 & -- & -- & -- & 2,200 \\
\hline & Heptachlorobiphenyls & 102 & 96 & -- & -- & -- & 99 \\
\hline & Octachlorobiphenyls & 19 & 18 & -- & -- & -- & 18 \\
\hline
\end{tabular}


Table 7. Halogenated organic compounds found in suspended-sediment samples collected during the June 1989 cruise.-Continued

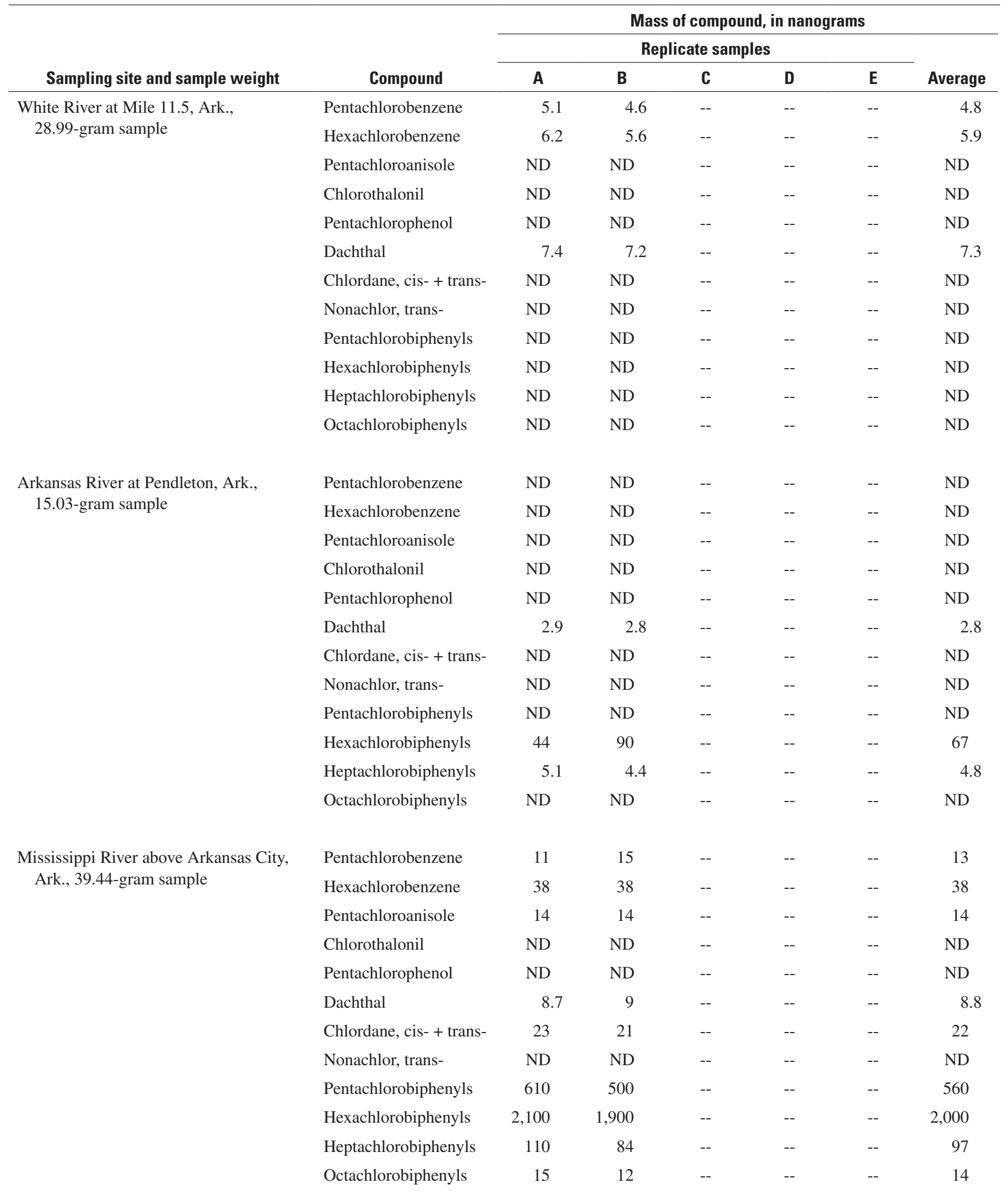


Table 7. Halogenated organic compounds found in suspended-sediment samples collected during the June 1989 cruise.-Continued

\begin{tabular}{|c|c|c|c|c|c|c|c|}
\hline \multirow[b]{3}{*}{ Sampling site and sample weight } & \multirow[b]{3}{*}{ Compound } & \multicolumn{6}{|c|}{ Mass of compound, in nanograms } \\
\hline & & \multicolumn{5}{|c|}{ Replicate samples } & \multirow[b]{2}{*}{ Average } \\
\hline & & A & B & C & D & $\mathbf{E}$ & \\
\hline \multirow{12}{*}{$\begin{array}{l}\text { Yazoo River below Steele Bayou, Miss., } \\
\text { 40.22-gram sample }\end{array}$} & Pentachlorobenzene & 16 & ND & -- & -- & -- & 16.3 \\
\hline & Hexachlorobenzene & 3.4 & ND & -- & -- & -- & 3.41 \\
\hline & Pentachloroanisole & 9.6 & ND & -- & -- & -- & 9.62 \\
\hline & Chlorothalonil & ND & ND & -- & -- & -- & $\mathrm{ND}$ \\
\hline & Pentachlorophenol & ND & ND & -- & -- & -- & ND \\
\hline & Dachthal & 1.8 & ND & -- & -- & -- & 1.78 \\
\hline & Chlordane, cis- + trans- & $\mathrm{ND}$ & ND & -- & -- & -- & $\mathrm{ND}$ \\
\hline & Nonachlor, trans- & ND & ND & -- & -- & -- & ND \\
\hline & Pentachlorobiphenyls & ND & ND & -- & -- & -- & ND \\
\hline & Hexachlorobiphenyls & ND & ND & -- & -- & -- & ND \\
\hline & Heptachlorobiphenyls & ND & ND & -- & -- & -- & ND \\
\hline & Octachlorobiphenyls & ND & ND & -- & -- & -- & ND \\
\hline \multirow{12}{*}{$\begin{array}{l}\text { Mississippi River below Vicksburg, } \\
\text { Miss., 39.01-gram sample }\end{array}$} & Pentachlorobenzene & 12 & 21 & ND & ND & 17 & 17 \\
\hline & Hexachlorobenzene & 39 & 48 & 27 & 32 & 42 & 38 \\
\hline & Pentachloroanisole & 5.6 & 24 & ND & ND & 16 & 15 \\
\hline & Chlorothalonil & ND & ND & ND & ND & ND & ND \\
\hline & Pentachlorophenol & ND & ND & ND & ND & ND & ND \\
\hline & Dachthal & 6.4 & 10.7 & ND & 5.2 & 8 & 7.6 \\
\hline & Chlordane, cis- + trans- & ND & 40 & ND & ND & 21 & 30 \\
\hline & Nonachlor, trans- & ND & 49 & ND & ND & 16 & 32 \\
\hline & Pentachlorobiphenyls & 270 & 770 & ND & ND & 480 & 510 \\
\hline & Hexachlorobiphenyls & 1,400 & 2,000 & 450 & 980 & 1,900 & 1,300 \\
\hline & Heptachlorobiphenyls & 74 & 157 & 28 & 40 & 90 & 78 \\
\hline & Octachlorobiphenyls & 13 & 30 & ND & ND & 16 & 20 \\
\hline \multirow{12}{*}{$\begin{array}{l}\text { Old River Outflow Channel near Knox } \\
\text { Landing, La., 35.86-gram sample }\end{array}$} & Pentachlorobenzene & 13 & 16 & -- & -- & -- & 14 \\
\hline & Hexachlorobenzene & 31 & 29 & -- & -- & -- & 30 \\
\hline & Pentachloroanisole & 18 & 16 & -- & -- & -- & 17 \\
\hline & Chlorothalonil & ND & ND & -- & -- & -- & ND \\
\hline & Pentachlorophenol & ND & ND & -- & -- & -- & ND \\
\hline & Dachthal & 5.9 & 5.5 & -- & -- & -- & 5.7 \\
\hline & Chlordane, cis- + trans- & 25 & 27 & -- & -- & -- & 26 \\
\hline & Nonachlor, trans- & 25 & 30 & -- & -- & -- & 28 \\
\hline & Pentachlorobiphenyls & 420 & 490 & -- & -- & -- & 460 \\
\hline & Hexachlorobiphenyls & 1,700 & 1,700 & -- & -- & -- & 1,700 \\
\hline & Heptachlorobiphenyls & 90 & 92 & -- & -- & -- & 91 \\
\hline & Octachlorobiphenyls & 14 & 16 & -- & -- & -- & 15 \\
\hline
\end{tabular}


Table 7. Halogenated organic compounds found in suspended-sediment samples collected during the June 1989 cruise.-Continued

\begin{tabular}{|c|c|c|c|c|c|c|c|}
\hline \multirow[b]{3}{*}{ Sampling site and sample weight } & \multirow[b]{3}{*}{ Compound } & \multicolumn{6}{|c|}{ Mass of compound, in nanograms } \\
\hline & & \multicolumn{5}{|c|}{ Replicate samples } & \multirow[b]{2}{*}{ Average } \\
\hline & & A & B & C & D & $\mathbf{E}$ & \\
\hline \multirow{12}{*}{$\begin{array}{l}\text { Mississippi River near St. Francisville, } \\
\text { La., 39.79-gram sample }\end{array}$} & Pentachlorobenzene & 17 & 18 & -- & -- & -- & 18 \\
\hline & Hexachlorobenzene & 39 & 37 & -- & -- & -- & 38 \\
\hline & Pentachloroanisole & 17 & 16 & -- & -- & -- & 16 \\
\hline & Chlorothalonil & ND & ND & -- & -- & -- & ND \\
\hline & Pentachlorophenol & ND & ND & -- & -- & -- & ND \\
\hline & Dachthal & 7.5 & 6.8 & -- & -- & -- & 7.2 \\
\hline & Chlordane, cis- + trans- & 36 & 29 & -- & -- & -- & 32 \\
\hline & Nonachlor, trans- & 31 & 18 & -- & -- & -- & 24 \\
\hline & Pentachlorobiphenyls & 530 & 600 & -- & -- & -- & 560 \\
\hline & Hexachlorobiphenyls & 1,800 & 1,700 & -- & -- & -- & 1,800 \\
\hline & Heptachlorobiphenyls & 98 & 87 & -- & -- & -- & 92 \\
\hline & Octachlorobiphenyls & 18 & 15 & -- & -- & -- & 16 \\
\hline \multirow{12}{*}{$\begin{array}{l}\text { Mississippi River below Belle Chasse, } \\
\text { La., 39.78-gram sample }\end{array}$} & Pentachlorobenzene & 12 & 15 & 17 & 5.8 & -- & 12 \\
\hline & Hexachlorobenzene & 110 & 130 & 130 & 100 & -- & 120 \\
\hline & Pentachloroanisole & ND & 17 & 20 & ND & -- & 18 \\
\hline & Chlorothalonil & ND & ND & ND & ND & -- & ND \\
\hline & Pentachlorophenol & ND & ND & ND & ND & -- & ND \\
\hline & Dachthal & 6.6 & 7 & 7.6 & 5 & -- & 6.6 \\
\hline & Chlordane, cis- + trans- & ND & ND & 19 & ND & -- & 19 \\
\hline & Nonachlor, trans- & ND & ND & ND & ND & -- & ND \\
\hline & Pentachlorobiphenyls & 220 & 680 & 410 & 100 & -- & 350 \\
\hline & Hexachlorobiphenyls & 1,200 & 2,700 & 1,600 & 730 & -- & 1,600 \\
\hline & Heptachlorobiphenyls & 54 & 107 & 86 & 41 & -- & 72 \\
\hline & Octachlorobiphenyls & 6.6 & 23 & 17 & ND & -- & 16 \\
\hline
\end{tabular}


Table 8. Halogenated organic compounds found in suspended-sediment samples collected during the February-March 1990 cruise.

[ND, not detected; --, no data; masses not corrected for recovery; all masses rounded to two significant figures]

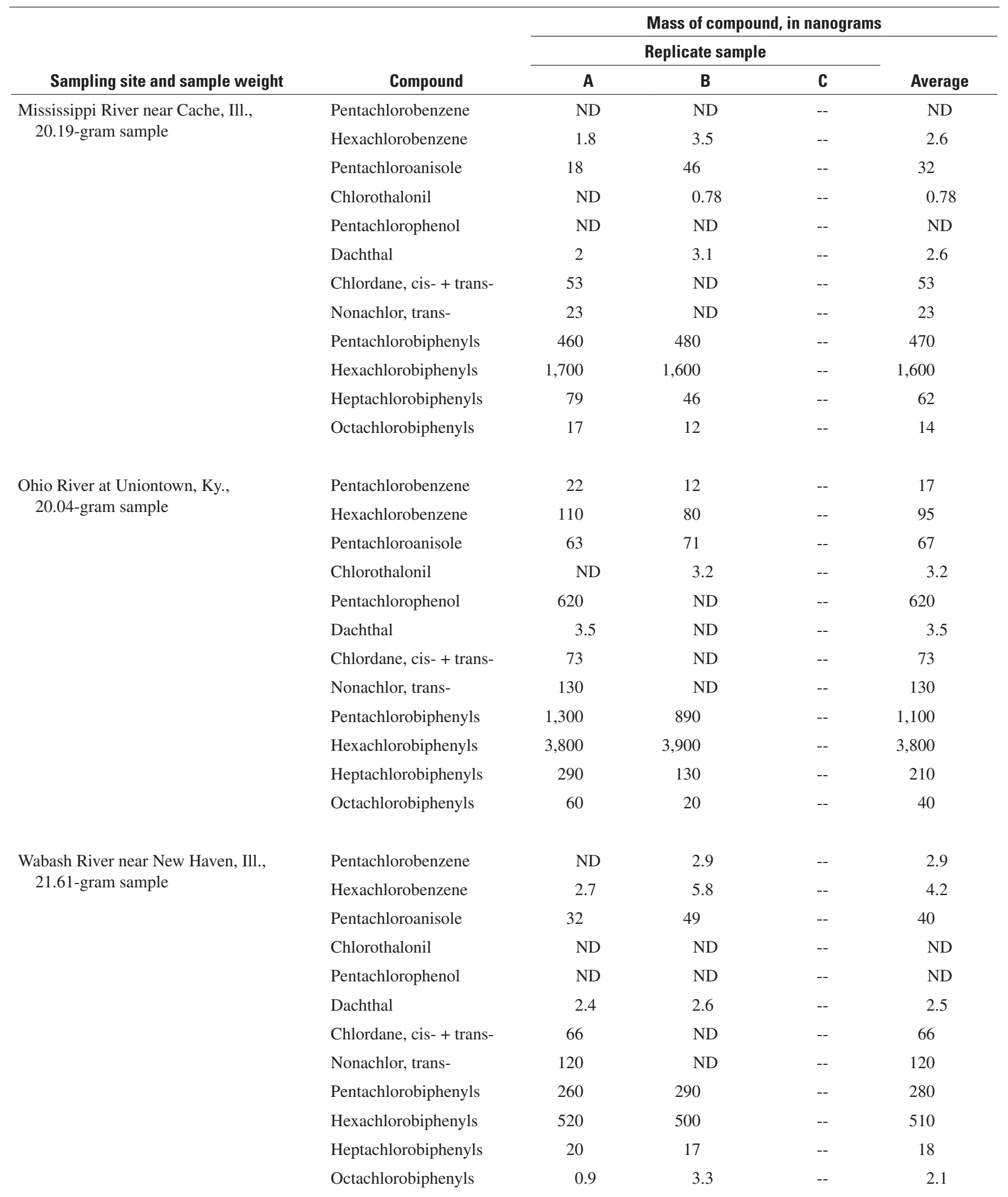


Table 8. Halogenated organic compounds found in suspended-sediment samples collected during the February-March 1990 cruise.Continued

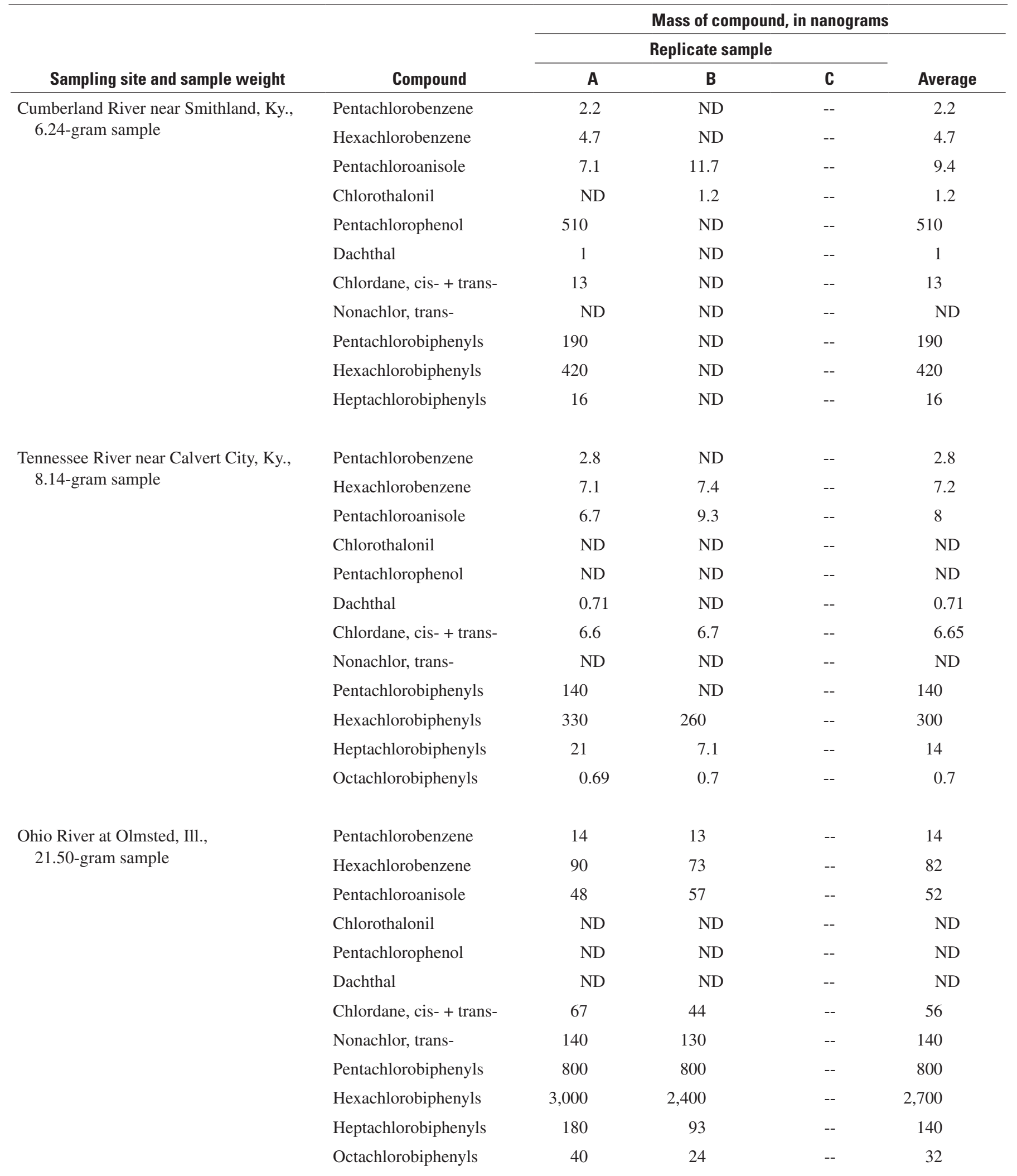


Table 8. Halogenated organic compounds found in suspended-sediment samples collected during the February-March 1990 cruise.Continued

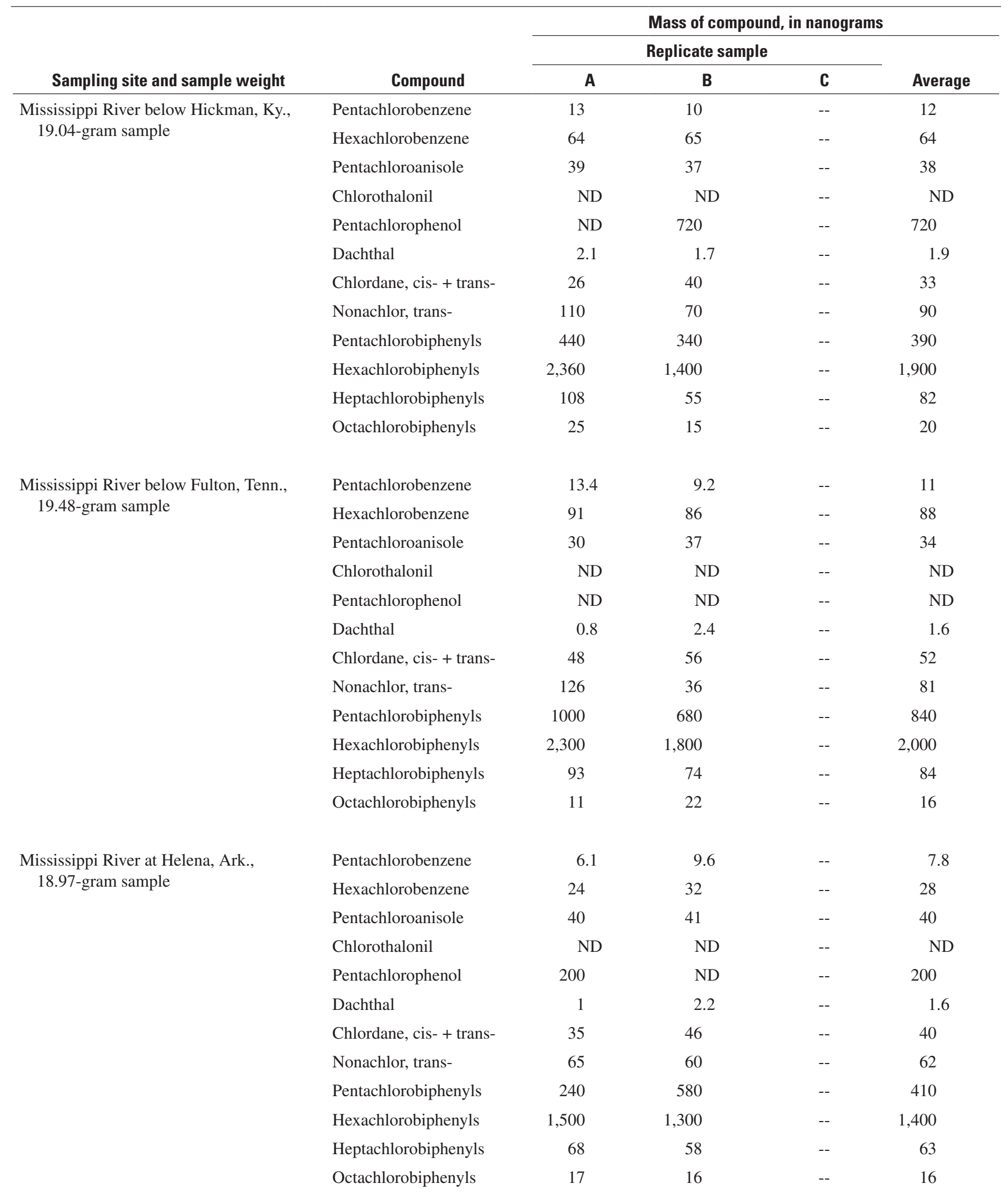


Table 8. Halogenated organic compounds found in suspended-sediment samples collected during the February-March 1990 cruise.Continued

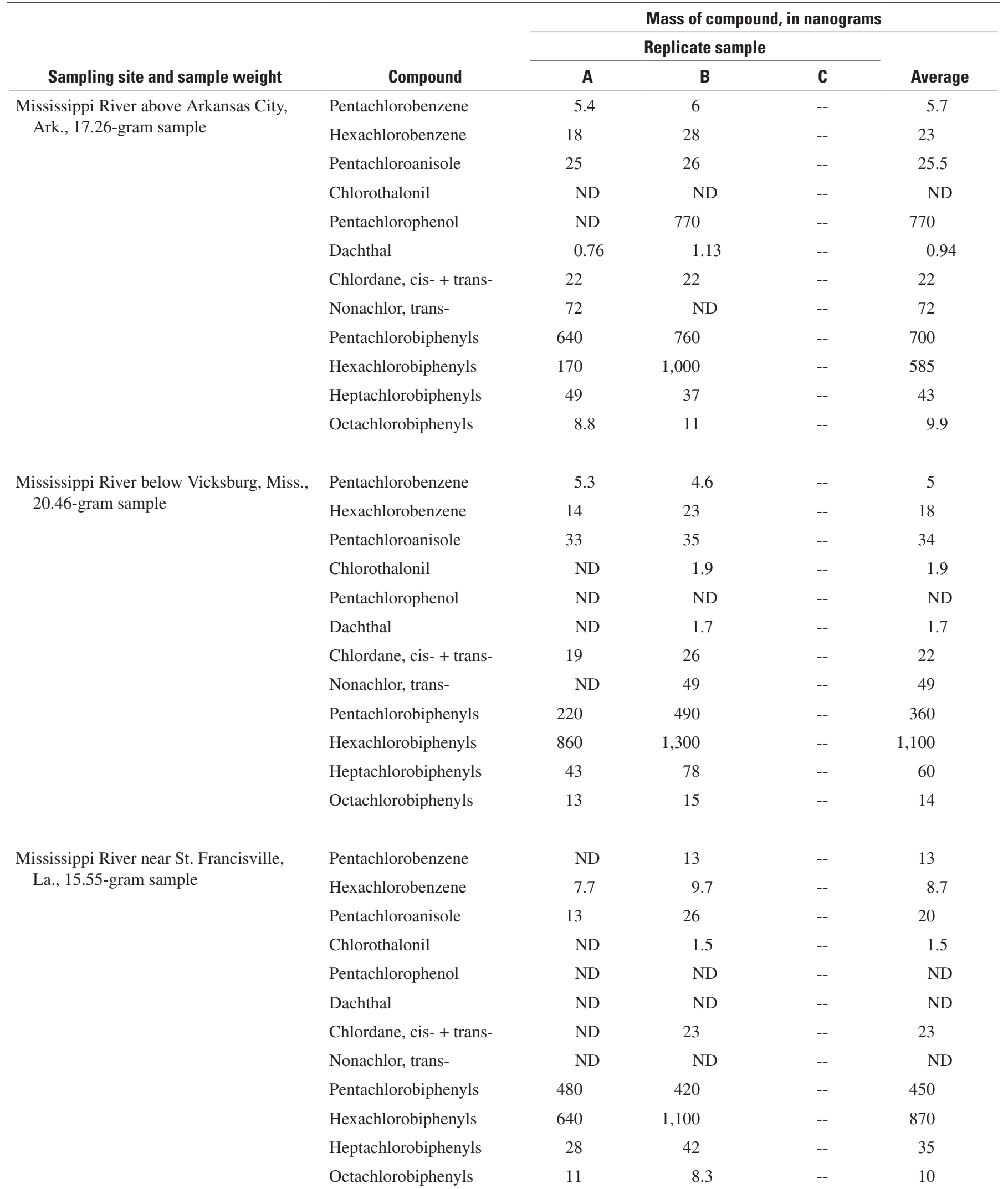


Table 8. Halogenated organic compounds found in suspended-sediment samples collected during the February-March 1990 cruise.Continued

\begin{tabular}{|c|c|c|c|c|c|}
\hline \multirow[b]{3}{*}{ Sampling site and sample weight } & \multirow[b]{3}{*}{ Compound } & \multicolumn{4}{|c|}{ Mass of compound, in nanograms } \\
\hline & & \multicolumn{3}{|c|}{ Replicate sample } & \multirow[b]{2}{*}{ Average } \\
\hline & & A & B & C & \\
\hline \multirow{7}{*}{$\begin{array}{l}\text { Mississippi River below Belle Chasse, La., } \\
\text { 20.12-gram sample }\end{array}$} & Hexachlorobenzene & 29 & 43 & -- & 36 \\
\hline & Pentachloroanisole & 20 & 25 & -- & 22 \\
\hline & Pentachlorophenol & ND & ND & -- & ND \\
\hline & Dachthal & 0.52 & 1.45 & -- & 0.99 \\
\hline & Chlordane, cis- + trans- & 18 & 42 & -- & 30 \\
\hline & Nonachlor, trans- & 34 & ND & -- & 34 \\
\hline & Octachlorobiphenyls & 11 & 15 & -- & 13 \\
\hline
\end{tabular}


Table 9. Halogenated organic compounds found in suspended-sediment samples collected during the May-June 1990 cruise.

[ND, not detected; --, no data; masses not corrected for recovery; all masses rounded to two significant figures]

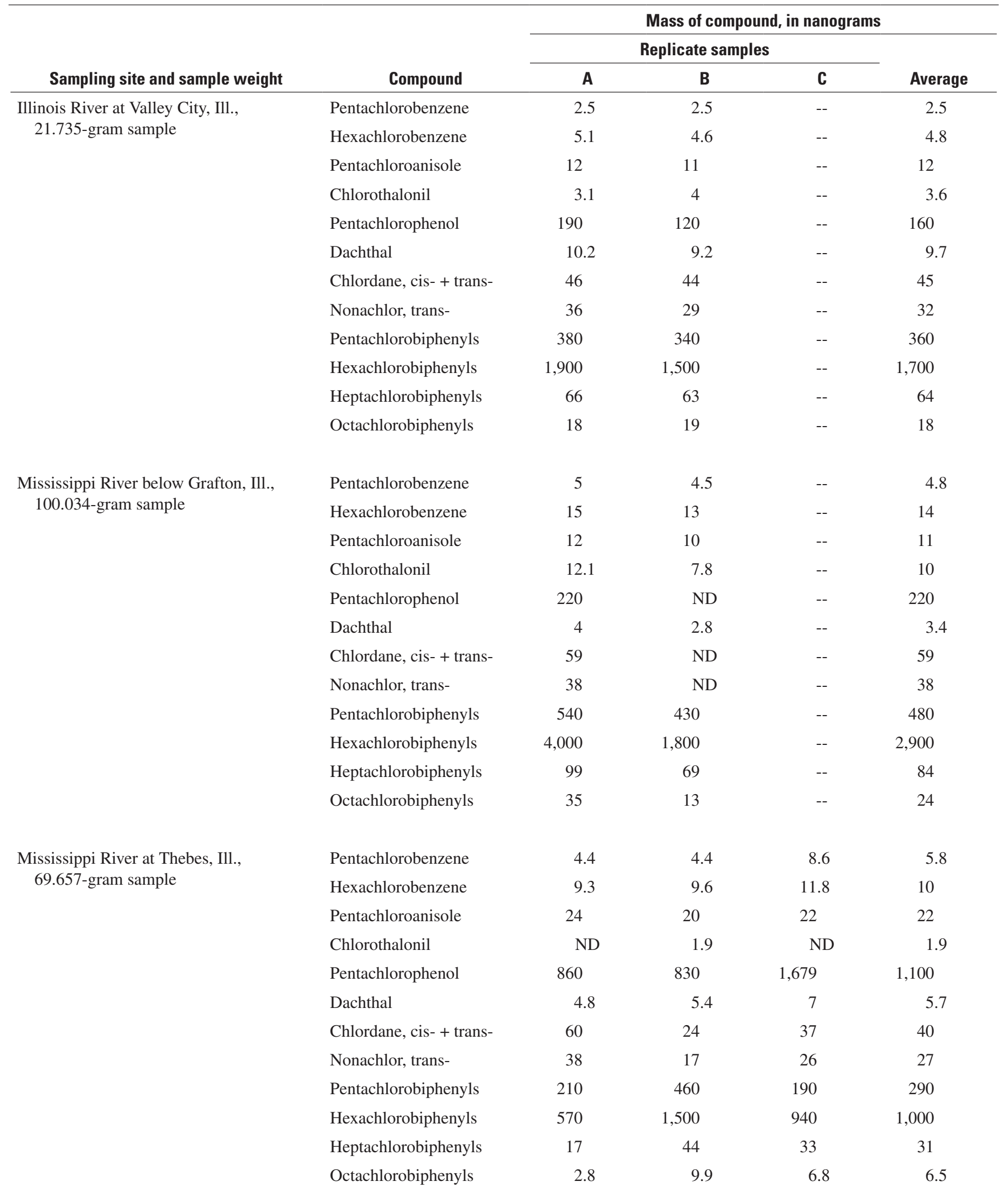


Table 9. Halogenated organic compounds found in suspended-sediment samples collected during the May-June 1990 cruise.Continued

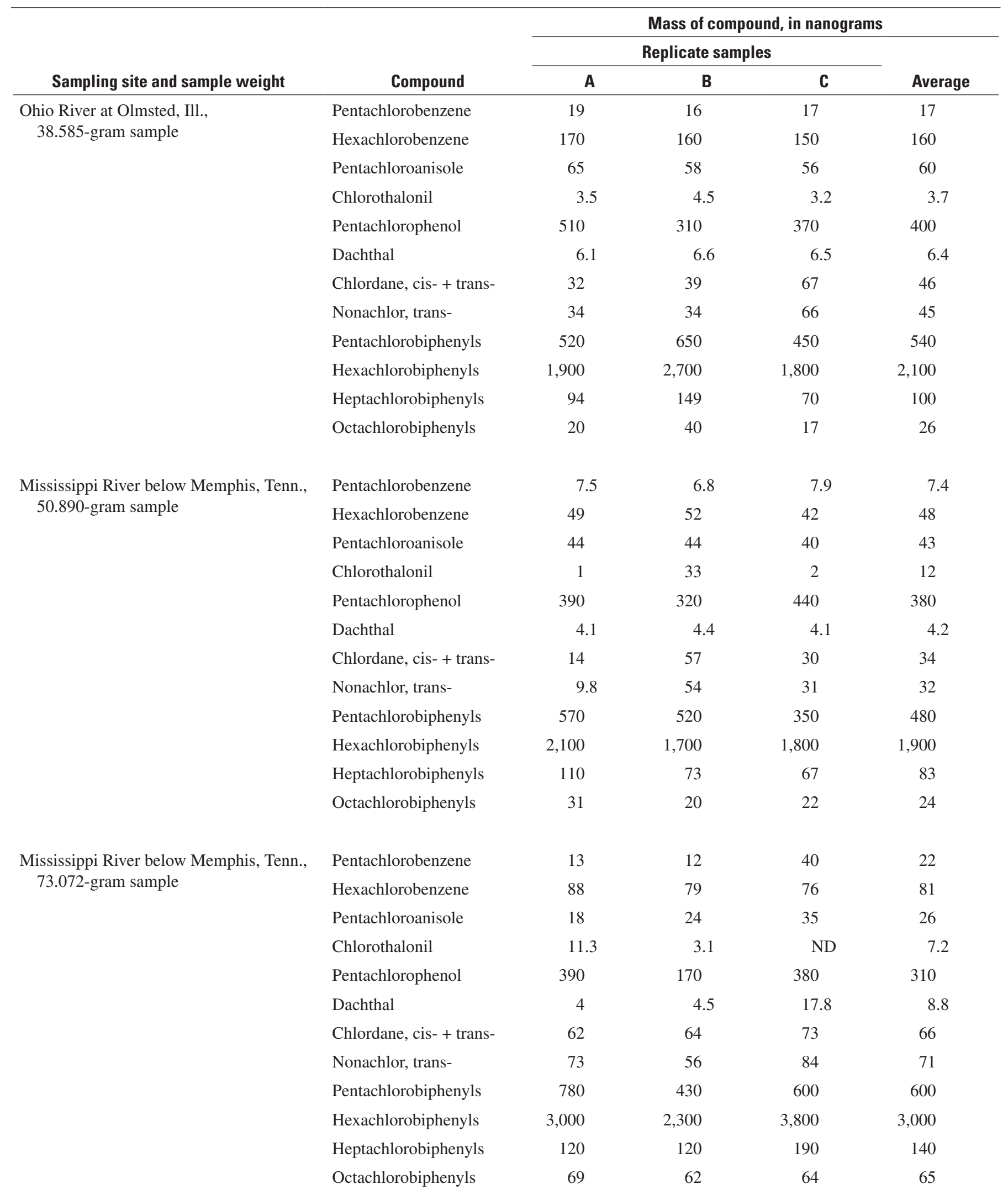


Table 9. Halogenated organic compounds found in suspended-sediment samples collected during the May-June 1990 cruise.Continued

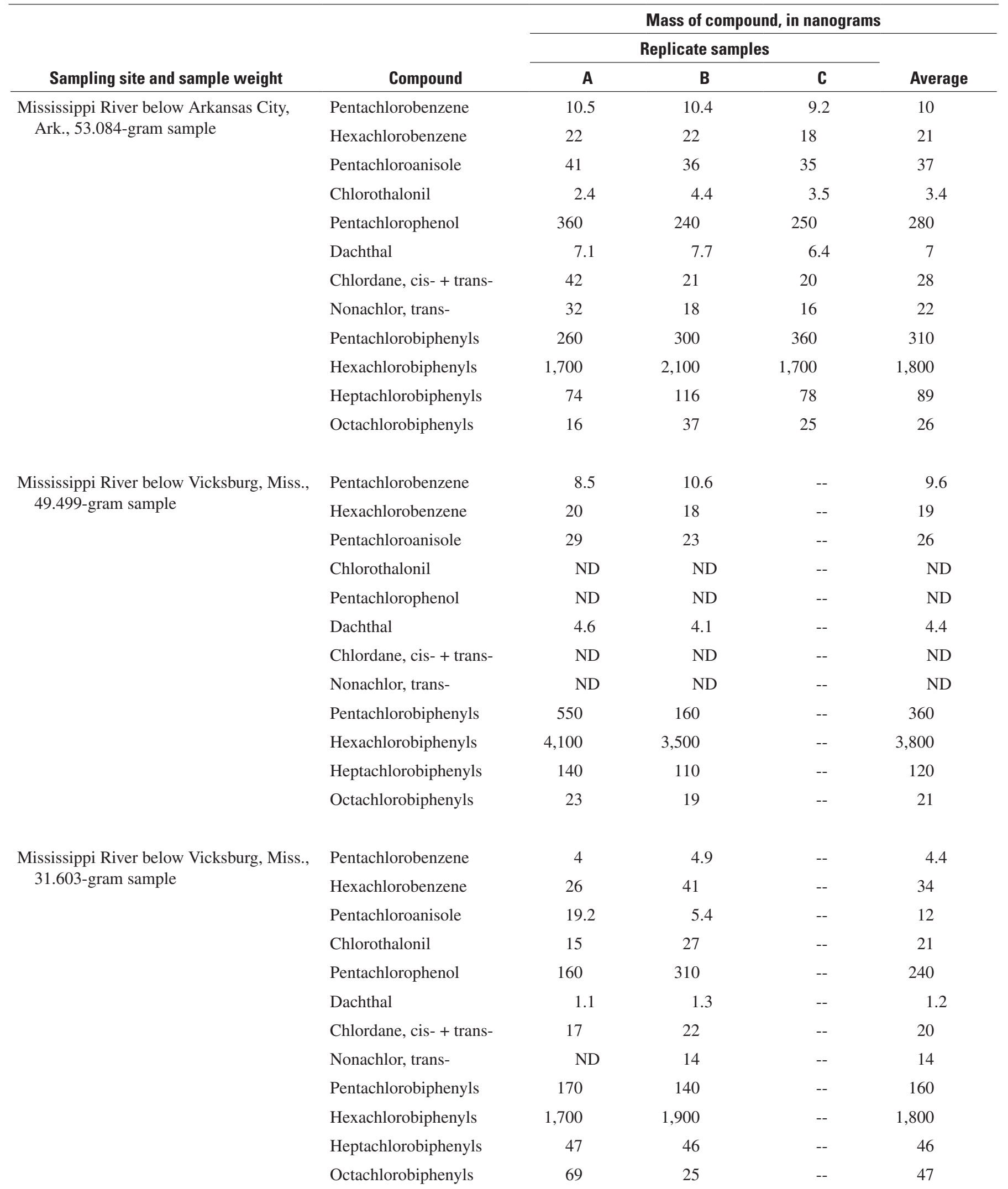


Table 9. Halogenated organic compounds found in suspended-sediment samples collected during the May-June 1990 cruise.Continued

\begin{tabular}{|c|c|c|c|c|c|}
\hline \multirow[b]{3}{*}{ Sampling site and sample weight } & \multirow[b]{3}{*}{ Compound } & \multicolumn{4}{|c|}{ Mass of compound, in nanograms } \\
\hline & & \multicolumn{3}{|c|}{ Replicate samples } & \multirow[b]{2}{*}{ Average } \\
\hline & & A & B & C & \\
\hline \multirow{7}{*}{$\begin{array}{l}\text { Mississippi River near St. Francisville, } \\
\text { La., 56.237-gram sample }\end{array}$} & Hexachlorobenzene & 31 & 29 & -- & 30 \\
\hline & Pentachloroanisole & 48 & 43 & -- & 46 \\
\hline & Pentachlorophenol & 230 & 260 & -- & 240 \\
\hline & Dachthal & 7.3 & 7 & -- & 7.2 \\
\hline & Chlordane, cis- + trans- & 18 & 32 & -- & 25 \\
\hline & Nonachlor, trans- & 19 & 27 & -- & 23 \\
\hline & Octachlorobiphenyls & 28 & 29 & -- & 28 \\
\hline \multirow{6}{*}{$\begin{array}{l}\text { Mississippi River below Belle Chasse, La., } \\
\text { 54.391-gram sample }\end{array}$} & Pentachlorobenzene & 17 & 15 & -- & 16 \\
\hline & Hexachlorobenzene & 73 & 67 & -- & 70 \\
\hline & Pentachloroanisole & 40 & 35 & -- & 38 \\
\hline & Chlorothalonil & 1.1 & 1.2 & -- & 1.2 \\
\hline & Pentachlorophenol & 180 & 220 & -- & 200 \\
\hline & Dachthal & 5.6 & 5.4 & -- & 5.5 \\
\hline
\end{tabular}


The data were not censored below the detection limit to avoid statistical distortions of the data that can occur (Helsel and Cohn, 1988). When no response occurred for a compound, a "not detected" (ND) designation is used. According to Helsel (1990), "deletion of censored data or fabrication of values for less-thans leads to undesirable and unnecessary errors."

Halogenated organic compounds found associated with suspended sediment in samples collected during the May-June 1988 cruise are shown in table 5. Sixteen sites were sampled during this cruise. The usual sample size was $15 \mathrm{~g}$ although less suspended sediment was available from some sites, such as the Ohio River at Olmsted.

Halogenated organic compounds found associated with suspended sediment in samples from 17 sites from the MarchApril 1989 cruise are shown in table 6. Spring runoff conditions on the Ohio River resulted in higher suspended-sediment concentrations, as seen in table 2, than in May-June 1988.

Larger sample sizes of nearly $40 \mathrm{~g}$ were extracted when available.
Suspended-sediment data from samples collected at 17 sites from the June 1989 cruise are shown in table 7. Spring runoff conditions on the Missouri River again produced high suspended-sediment concentrations on the Mississippi River, enabling larger sample sizes to be collected and extracted.

During the February-March 1990 cruise, samples were collected at only 13 sites, many of them different from previous trips, as shown in table 8 . Sample sizes averaged about $18 \mathrm{~g}$.

The organic compound data for samples collected during the May-June 1990 cruise are shown in table 9. The extracted sample sizes varied widely. A new, higher capacity balance allowed sample weights to be measured to thousandths of a gram.

The relative standard deviation (RSD) was determined for the replicate analyses of each compound for each sample, data permitting. For each cruise, the average RSD was determined for each compound and is shown in table 10, along with an average for all cruises.

Table 10. Average relative standard deviation, in percent, for replicate analyses.

$[--$, insufficient data for calculation $]$

\begin{tabular}{|c|c|c|c|c|c|c|}
\hline \multirow[b]{2}{*}{ Compound } & \multicolumn{5}{|c|}{ Cruise } & \multirow[b]{2}{*}{ Average } \\
\hline & $\begin{array}{l}\text { May-June } \\
1988\end{array}$ & $\begin{array}{c}\text { March-April } \\
1989\end{array}$ & June 1989 & $\begin{array}{c}\text { February- } \\
\text { March } 1990\end{array}$ & $\begin{array}{c}\text { May-June } \\
1990\end{array}$ & \\
\hline Pentachlorobenzene & 15 & 29 & 17 & 24 & 17 & 20 \\
\hline Hexachlorobenzene & 16 & 19 & 9 & 22 & 10 & 15 \\
\hline Pentachloroanisole & 20 & 20 & 20 & 20 & 18 & 19 \\
\hline Chlorothalonil & 50 & 38 & -- & 44 & 48 & 45 \\
\hline Pentachlorophenol & -- & 34 & -- & -- & 27 & 30 \\
\hline Dachthal & 25 & 29 & 13 & 39 & 17 & 25 \\
\hline Chlordane, cis- + trans- & 18 & 26 & 20 & 21 & 31 & 23 \\
\hline Nonachlor, trans- & 29 & 34 & 23 & 31 & 48 & 33 \\
\hline Pentachlorobiphenyls & 13 & 42 & 28 & 24 & 27 & 27 \\
\hline Hexachlorobiphenyls & 15 & 29 & 25 & 26 & 20 & 23 \\
\hline Heptachlorobiphenyls & 19 & 29 & 27 & 33 & 23 & 26 \\
\hline Octachlorobiphenyls & 52 & 35 & 17 & 30 & 32 & 34 \\
\hline
\end{tabular}


At the Missouri River site on June 7, 1989, there was sufficient material from the depth-integrated composite sample to compare it with the pumped composite sample. Both suspended-sediment samples were discharge-weighted water samples taken at each vertical; however, the pumped sample was not depth integrated. Different sample sizes were extracted. Table 11 includes compound mass and sample weight of the suspended sediment from the discharge-weighted samples collected by pumping and by depth integration.
The suspended-sediment extracts from 17 samples collected during the June 1989 cruise and 8 samples collected during the February-March 1990 cruise were reanalyzed for EPA priority pollutants. The concentration, in microgram $/ \mathrm{kg}$ of dry suspended sediment (rather than mass as in previous tables), of each of the selected priority pollutants in selected samples is presented in table 12 for the June 1989 cruise and table 13 for the February-March 1990 cruise. The compounds of primary interest were the polycyclic aromatic hydrocarbons.

Table 11. Halogenated organic compounds in suspended-sediment depth-integrated and pumped samples collected June 7, 1989 from the Missouri River at Hermann, Missouri.

[ND, not detected]

\begin{tabular}{|c|c|c|c|c|}
\hline \multirow[b]{3}{*}{ Sample type and weight } & \multirow[b]{3}{*}{ Compound } & \multicolumn{3}{|c|}{ Mass in nanograms } \\
\hline & & \multicolumn{2}{|c|}{ Replicates } & \multirow[b]{2}{*}{ Average } \\
\hline & & A & B & \\
\hline \multirow[t]{12}{*}{ Pumped, 40.11-gram sample } & Pentachlorobenzene & 3.66 & 1.3 & 2.5 \\
\hline & Hexachlorobenzene & 4.9 & 2.6 & 3.8 \\
\hline & Pentachloroanisole & 4.3 & 1.8 & 3 \\
\hline & Chlorothalonil & 1.2 & ND & 1.2 \\
\hline & Pentachlorophenol & 130 & ND & 130 \\
\hline & Dachthal & 7.8 & 4.7 & 6.2 \\
\hline & Chlordane, cis- + trans- & 31 & 18 & 24 \\
\hline & Nonachlor, trans- & 41 & 15 & 28 \\
\hline & Pentachlorobiphenyls & 47 & ND & 47 \\
\hline & Hexachlorobiphenyls & 310 & 150 & 231 \\
\hline & Heptachlorobiphenyls & 15.5 & 6.4 & 11 \\
\hline & Octachlorobiphenyls & 1.4 & ND & 1.4 \\
\hline \multirow[t]{12}{*}{ Depth integrated, 21.16-gram sample } & Pentachlorobenzene & 4.4 & 5.1 & 4.8 \\
\hline & Hexachlorobenzene & 5.1 & 5.2 & 5.2 \\
\hline & Pentachloroanisole & 3.9 & 2.4 & 3.2 \\
\hline & Chlorothalonil & ND & ND & ND \\
\hline & Pentachlorophenol & ND & ND & ND \\
\hline & Dachthal & 8.2 & 8.4 & 8.3 \\
\hline & Chlordane, cis- + trans- & 7.5 & 5.8 & 6.6 \\
\hline & Nonachlor, trans- & ND & 6.8 & 6.8 \\
\hline & Pentachlorobiphenyls & 34 & 15 & 24.5 \\
\hline & Hexachlorobiphenyls & 76 & 73 & 74.6 \\
\hline & Heptachlorobiphenyls & 3.4 & 3.8 & 3.6 \\
\hline & Octachlorobiphenyls & ND & ND & ND \\
\hline
\end{tabular}


Table 12. Hydrophobic U.S. Environmental Protection Agency priority pollutants detected in suspended-sediment samples collected during the June 1989 cruise.

[All concentrations in micrograms per kilogram dry sediment; ND, not detected]

\begin{tabular}{|c|c|c|c|}
\hline \multirow[b]{2}{*}{ Compound } & \multicolumn{3}{|c|}{ Sampling site } \\
\hline & $\begin{array}{c}\text { Mississippi River } \\
\text { near Winfield, Mo. }\end{array}$ & $\begin{array}{l}\text { Illinois River at } \\
\text { Hardin, III. }\end{array}$ & $\begin{array}{c}\text { Missouri River at } \\
\text { Hermann, Mo. }\end{array}$ \\
\hline phenol & 18 & ND & 33 \\
\hline benzene, 1,3-dichloro- & ND & ND & 1.8 \\
\hline benzene, 1,4-dichloro- & ND & ND & 0.32 \\
\hline benzene, 1,2-dichloro- & ND & ND & 0.25 \\
\hline nitrobenzene & ND & ND & ND \\
\hline benzene, 1,2,4-trichloro- & ND & ND & ND \\
\hline naphthalene & 7.2 & 2.3 & 2.8 \\
\hline acenaphthylene & 7.6 & 20 & 0.31 \\
\hline dimethylphthalate & 40 & 16 & 10 \\
\hline acenaphthene & 2.8 & 2.4 & 0.88 \\
\hline toluene, 2,4-dinitro- & ND & ND & ND \\
\hline fluorene & 9.9 & 4.7 & 1.2 \\
\hline diethylphthalate & 200 & 80 & 60 \\
\hline hexachlorobenzene & ND & ND & ND \\
\hline phenanthrene & 58 & 29 & 12 \\
\hline anthracene & 7.6 & 6 & 0.67 \\
\hline di-n-butylphthalate & 760 & 630 & 290 \\
\hline fluoranthene & 43 & 66 & 11 \\
\hline pyrene & 36 & 78 & 8.3 \\
\hline butylbenzylphthalate & 510 & 260 & 53 \\
\hline benz(a)anthracene & 10 & 28 & 3.8 \\
\hline chrysene & 21 & 44 & 7.5 \\
\hline bis(2-ethylhexyl)phthalate & 1,500 & 660 & 1,100 \\
\hline di-n-octylphthalate & ND & ND & 4.2 \\
\hline benzo(b)fluoranthene & 23 & 65 & 6 \\
\hline benzo(k)fluoranthene & 14 & 39 & 5 \\
\hline benzo(a)pyrene & 20 & 25 & 39 \\
\hline indeno(1,2,3-cd)pyrene & 28 & 60 & 11 \\
\hline $\operatorname{dibenz}(\mathrm{a}, \mathrm{h})$ anthracene & ND & 14 & ND \\
\hline benzo(g,h,i)perylene & 25 & 56 & ND \\
\hline
\end{tabular}


Table 12. Hydrophobic U.S. Environmental Protection Agency priority pollutants detected in suspended-sediment samples collected during the June 1989 cruise.-Continued

\begin{tabular}{|c|c|c|c|}
\hline \multirow[b]{2}{*}{ Compound } & \multicolumn{3}{|c|}{ Sampling site } \\
\hline & $\begin{array}{c}\text { Mississippi River at } \\
\text { St. Louis, Mo. }\end{array}$ & $\begin{array}{c}\text { Mississippi River at } \\
\text { Thebes, III. }\end{array}$ & $\begin{array}{l}\text { Ohio River at } \\
\text { Olmsted, III. }\end{array}$ \\
\hline phenol & 38 & 33 & 39 \\
\hline benzene, 1,3-dichloro- & 2.6 & 4 & 3.6 \\
\hline benzene, 1,4-dichloro- & 0.51 & 0.74 & 1.1 \\
\hline benzene, 1,2-dichloro- & 0.44 & 0.62 & 0.93 \\
\hline nitrobenzene & 0.43 & 0.96 & ND \\
\hline benzene, 1,2,4-trichloro- & ND & ND & 4 \\
\hline naphthalene & 8.4 & 6.2 & 33 \\
\hline acenaphthylene & 5.2 & 6.7 & 13 \\
\hline dimethylphthalate & 28 & 17 & 29 \\
\hline acenaphthene & 2.5 & 3 & 6.2 \\
\hline toluene, 2,4-dinitro- & ND & ND & ND \\
\hline fluorene & 5.4 & 6.3 & 13 \\
\hline diethylphthalate & 160 & 96 & 120 \\
\hline hexachlorobenzene & ND & ND & 2 \\
\hline phenanthrene & 53 & 41 & 124 \\
\hline anthracene & 6.8 & 6 & 120 \\
\hline di-n-butylphthalate & 370 & 320 & 400 \\
\hline fluoranthene & 46 & 62 & 97 \\
\hline pyrene & 42 & 60 & 76 \\
\hline butylbenzylphthalate & 170 & 110 & 390 \\
\hline benz(a)anthracene & 22 & 37 & 46 \\
\hline chrysene & 40 & 51 & 89 \\
\hline bis(2-ethylhexyl)phthalate & 2,000 & 770 & 1,400 \\
\hline di-n-octylphthalate & 34 & ND & ND \\
\hline benzo(b)fluoranthene & 63 & 85 & 190 \\
\hline benzo(k)fluoranthene & 40 & 36 & 97 \\
\hline benzo(a)pyrene & 19 & 27 & 22 \\
\hline indeno(1,2,3-cd)pyrene & 45 & 45 & 170 \\
\hline $\operatorname{dibenz}(\mathrm{a}, \mathrm{h})$ anthracene & 8.4 & 8.9 & 50 \\
\hline benzo(g,h,i)perylene & 44 & 41 & 180 \\
\hline
\end{tabular}


Table 12. Hydrophobic U.S. Environmental Protection Agency priority pollutants detected in suspended-sediment samples collected during the June 1989 cruise.-Continued

\begin{tabular}{|c|c|c|c|}
\hline \multirow[b]{2}{*}{ Compound } & \multicolumn{3}{|c|}{ Sampling site } \\
\hline & $\begin{array}{c}\text { Mississippi River } \\
\text { below Hickman, Ky. }\end{array}$ & $\begin{array}{l}\text { Mississippi River at } \\
\text { Fulton, Tenn. }\end{array}$ & $\begin{array}{c}\text { Mississippi River at } \\
\text { Helena, Ark. }\end{array}$ \\
\hline phenol & 18 & 45 & 0.95 \\
\hline benzene, 1,3-dichloro- & 2.5 & 3.2 & 3.7 \\
\hline benzene, 1,4-dichloro- & 0.47 & 0.76 & 1 \\
\hline benzene, 1,2-dichloro- & 0.43 & 0.62 & 0.94 \\
\hline nitrobenzene & ND & ND & ND \\
\hline benzene, 1,2,4-trichloro- & 0.94 & 1.8 & 1.8 \\
\hline naphthalene & 8.7 & 16 & 20 \\
\hline acenaphthylene & 13 & 7.3 & 3.9 \\
\hline dimethylphthalate & 38 & 38 & 27 \\
\hline acenaphthene & 5.5 & 2.1 & ND \\
\hline toluene, 2,4-dinitro- & ND & ND & ND \\
\hline fluorene & 11 & 5.6 & 6.1 \\
\hline diethylphthalate & 200 & 190 & 140 \\
\hline hexachlorobenzene & ND & 0.78 & 0.69 \\
\hline phenanthrene & 98 & 59 & 48 \\
\hline anthracene & 16 & 8.2 & 4.4 \\
\hline di-n-butylphthalate & 220 & 200 & 130 \\
\hline fluoranthene & 98 & 67 & 50 \\
\hline pyrene & 97 & 58 & 40 \\
\hline butylbenzylphthalate & 210 & 180 & 95 \\
\hline benz(a)anthracene & 50 & 29 & 26 \\
\hline chrysene & 69 & 50 & 46 \\
\hline bis(2-ethylhexyl)phthalate & 410 & 810 & 570 \\
\hline di-n-octylphthalate & ND & ND & 12 \\
\hline benzo(b)fluoranthene & 120 & 88 & 200 \\
\hline benzo(k)fluoranthene & 38 & 53 & 8.7 \\
\hline benzo(a)pyrene & 48 & 14 & 13 \\
\hline indeno(1,2,3-cd)pyrene & 64 & 63 & 86 \\
\hline dibenz(a,h)anthracene & 12 & 10 & 17 \\
\hline benzo(g,h,i)perylene & 59 & 59 & 79 \\
\hline
\end{tabular}


Table 12. Hydrophobic U.S. Environmental Protection Agency priority pollutants detected in suspended-sediment samples collected during the June 1989 cruise.-Continued

\begin{tabular}{|c|c|c|c|}
\hline \multirow[b]{2}{*}{ Compound } & \multicolumn{3}{|c|}{ Sampling site } \\
\hline & $\begin{array}{l}\text { White River at } \\
\text { Mile 11.5, Ark. }\end{array}$ & $\begin{array}{l}\text { Arkansas River at } \\
\text { Pendleton, Ark. }\end{array}$ & $\begin{array}{c}\text { Mississippi River } \\
\text { above Arkansas City, } \\
\text { Ark. }\end{array}$ \\
\hline phenol & 34 & 39 & 120 \\
\hline benzene, 1,3-dichloro- & 2 & 4.9 & 0.99 \\
\hline benzene, 1,4-dichloro- & 0.28 & 0.75 & 0.85 \\
\hline benzene, 1,2-dichloro- & 0.3 & 0.79 & 1.3 \\
\hline nitrobenzene & ND & ND & ND \\
\hline benzene, 1,2,4-trichloro- & ND & ND & 2.4 \\
\hline naphthalene & 4 & 7.4 & 25 \\
\hline acenaphthylene & 0.19 & 0.97 & 9.4 \\
\hline dimethylphthalate & 61 & 42 & 23 \\
\hline acenaphthene & ND & ND & 4.1 \\
\hline toluene, 2,4-dinitro- & ND & ND & ND \\
\hline fluorene & 2.2 & 5 & 8.6 \\
\hline diethylphthalate & 34 & 220 & 120 \\
\hline hexachlorobenzene & ND & ND & 0.87 \\
\hline phenanthrene & 23 & 31 & 61 \\
\hline anthracene & 0.28 & 1.9 & 11 \\
\hline di-n-butylphthalate & 290 & 220 & 110 \\
\hline fluoranthene & 6.6 & 19 & 60 \\
\hline pyrene & 3.4 & 16 & 53 \\
\hline butylbenzylphthalate & 180 & 130 & 200 \\
\hline benz(a)anthracene & 1.5 & 11 & 32 \\
\hline chrysene & 3.6 & 22 & 56 \\
\hline bis(2-ethylhexyl)phthalate & 1,200 & 5,800 & 5,400 \\
\hline di-n-octylphthalate & 42 & ND & ND \\
\hline benzo(b)fluoranthene & 1.9 & 19 & 80 \\
\hline benzo(k)fluoranthene & 1.7 & 11 & 57 \\
\hline benzo(a)pyrene & ND & 6.6 & 29 \\
\hline indeno(1,2,3-cd)pyrene & ND & 8.7 & 90 \\
\hline $\operatorname{dibenz}(\mathrm{a}, \mathrm{h})$ anthracene & ND & ND & 15 \\
\hline benzo(g,h,i)perylene & ND & 14 & 88 \\
\hline
\end{tabular}


Table 12. Hydrophobic U.S. Environmental Protection Agency priority pollutants detected in suspended-sediment samples collected during the June 1989 cruise.-Continued

\begin{tabular}{|c|c|c|c|}
\hline \multirow[b]{2}{*}{ Compound } & \multicolumn{3}{|c|}{ Sampling site } \\
\hline & $\begin{array}{c}\text { Yazoo River } \\
\text { below Steele } \\
\text { Bayou, Miss. }\end{array}$ & $\begin{array}{c}\text { Mississippi } \\
\text { River below } \\
\text { Vicksburg, Miss. }\end{array}$ & $\begin{array}{l}\text { OutflowChannel } \\
\text { near Knox } \\
\text { Landing, La. }\end{array}$ \\
\hline phenol & 56 & 15 & 150 \\
\hline benzene, 1,3-dichloro- & 0.93 & 1.2 & 1.6 \\
\hline benzene, 1,4-dichloro- & 0.93 & 0.16 & 1.1 \\
\hline benzene, 1,2-dichloro- & 0.74 & 0.21 & 1.3 \\
\hline nitrobenzene & ND & ND & ND \\
\hline benzene, 1,2,4-trichloro- & ND & 0.7 & 2.1 \\
\hline naphthalene & 3.4 & 6.7 & 22 \\
\hline acenaphthylene & 0.22 & 2.1 & 10 \\
\hline dimethylphthalate & 17 & 8.6 & 13 \\
\hline acenaphthene & ND & 0.72 & 3.5 \\
\hline toluene, 2,4-dinitro- & ND & ND & ND \\
\hline fluorene & 0.8 & 2.4 & 3.5 \\
\hline diethylphthalate & 91 & 44 & 29 \\
\hline hexachlorobenzene & ND & 0.34 & ND \\
\hline phenanthrene & 7 & 25 & 55 \\
\hline anthracene & 0.35 & 3 & 7 \\
\hline di-n-butylphthalate & 120 & 48 & 85 \\
\hline fluoranthene & 5 & 30 & 45 \\
\hline pyrene & 3.2 & 27 & 40 \\
\hline butylbenzylphthalate & 72 & 41 & 110 \\
\hline benz(a)anthracene & 0.72 & 14 & 22 \\
\hline chrysene & 2.7 & 19 & 46 \\
\hline bis(2-ethylhexyl)phthalate & 150 & 1,800 & 650 \\
\hline di-n-octylphthalate & 3 & ND & 11 \\
\hline benzo(b)fluoranthene & 4.4 & 11 & 120 \\
\hline benzo(k)fluoranthene & 1.7 & 15 & 69 \\
\hline benzo(a)pyrene & 5.8 & 4.3 & 14 \\
\hline indeno(1,2,3-cd)pyrene & ND & 14 & 110 \\
\hline $\operatorname{dibenz}(\mathrm{a}, \mathrm{h})$ anthracene & ND & ND & 24 \\
\hline benzo(g,h,i)perylene & ND & 12 & 120 \\
\hline
\end{tabular}


Table 12. Hydrophobic U.S. Environmental Protection Agency priority pollutants detected in suspended-sediment samples collected during the June 1989 cruise.-Continued

\begin{tabular}{|c|c|c|c|c|}
\hline \multirow[b]{2}{*}{ Compound } & \multicolumn{2}{|c|}{ Sampling site } & \multirow[b]{2}{*}{ Procedure blank } & \multirow[b]{2}{*}{ Procedure blank } \\
\hline & $\begin{array}{l}\text { Mississippi River } \\
\text { near St. Francisville, } \\
\text { La. }\end{array}$ & $\begin{array}{c}\text { Mississippi River } \\
\text { belowBelle Chasse, } \\
\text { La. }\end{array}$ & & \\
\hline phenol & 44 & 33 & 5.3 & 10 \\
\hline benzene, 1,3-dichloro- & 2.3 & 2.4 & 0.82 & 0.77 \\
\hline benzene, 1,4-dichloro- & 1.4 & 0.4 & 0.14 & 0.12 \\
\hline benzene, 1,2-dichloro- & 1.1 & 0.4 & 0.15 & 0.15 \\
\hline nitrobenzene & ND & ND & ND & ND \\
\hline benzene, 1,2,4-trichloro- & 2 & 1.1 & ND & ND \\
\hline naphthalene & 17 & 8.5 & 0.55 & 0.5 \\
\hline acenaphthylene & 3.4 & 6.9 & ND & ND \\
\hline dimethylphthalate & 27 & 33 & 1.5 & 1.6 \\
\hline acenaphthene & 3 & 3.3 & ND & ND \\
\hline toluene, 2,4-dinitro- & 1.3 & ND & ND & ND \\
\hline fluorene & 5 & 5.6 & ND & ND \\
\hline diethylphthalate & ND & 190 & 4.1 & 3.8 \\
\hline hexachlorobenzene & 0.76 & 2.7 & ND & ND \\
\hline phenanthrene & 50 & 57 & 0.38 & 0.35 \\
\hline anthracene & 4.1 & 8.4 & ND & ND \\
\hline di-n-butylphthalate & 120 & 210 & 23 & 25 \\
\hline fluoranthene & 48 & 59 & 0.29 & 0.2 \\
\hline pyrene & 40 & 51 & ND & ND \\
\hline butylbenzylphthalate & 110 & 220 & 0.98 & ND \\
\hline benz(a)anthracene & 21 & 29 & ND & ND \\
\hline chrysene & 33 & 47 & ND & ND \\
\hline bis(2-ethylhexyl)phthalate & 320 & 2,300 & 11,200 & 15,000 \\
\hline di-n-octylphthalate & ND & ND & 570 & 290 \\
\hline benzo(b)fluoranthene & 110 & 80 & ND & ND \\
\hline benzo(k)fluoranthene & 59 & 32 & ND & ND \\
\hline benzo(a)pyrene & 19 & 21 & ND & ND \\
\hline indeno(1,2,3-cd)pyrene & 70 & 49 & ND & ND \\
\hline dibenz $(\mathrm{a}, \mathrm{h})$ anthracene & 17 & 12 & ND & ND \\
\hline benzo(g,h,i)perylene & 72 & 51 & ND & ND \\
\hline
\end{tabular}


Table 13. Hydrophobic U.S. Environmental Protection Agency priority pollutants detected in suspended-sediment samples collected during the February-March 1990 cruise.

[All concentrations in micrograms per kilogram dry sediment; ND, not detected]

\begin{tabular}{|c|c|c|c|}
\hline \multirow[b]{2}{*}{ Compound } & \multicolumn{3}{|c|}{ Sampling site } \\
\hline & $\begin{array}{l}\text { Ohio River at } \\
\text { Olmsted, III. }\end{array}$ & $\begin{array}{c}\text { Mississippi River } \\
\text { below Hickman, Ky. }\end{array}$ & $\begin{array}{l}\text { Mississippi River } \\
\text { below Fulton, Tenn. }\end{array}$ \\
\hline phenol & 53 & 44 & 44 \\
\hline benzene, 1,3-dichloro- & 0.5 & 0.5 & ND \\
\hline benzene, 1,4-dichloro- & 5.3 & 3.3 & 2 \\
\hline benzene, 1,2-dichloro- & 2.5 & 1.1 & 0.54 \\
\hline nitrobenzene & ND & ND & ND \\
\hline benzene, 1,2,4-trichloro- & 17 & 9.7 & 4.4 \\
\hline naphthalene & 47 & 29 & 23 \\
\hline acenaphthylene & 7.8 & 29 & 18 \\
\hline dimethylphthalate & 7 & 8 & 6.4 \\
\hline acenaphthene & 13 & 9.3 & 6.9 \\
\hline toluene, 2,4-dinitro- & ND & ND & ND \\
\hline fluorene & 19 & 16 & 12 \\
\hline diethylphthalate & 5.9 & 6.9 & 6.8 \\
\hline hexachlorobenzene & 3.6 & 2.6 & 2.8 \\
\hline phenanthrene & 160 & 120 & 92 \\
\hline anthracene & 27 & 38 & 26 \\
\hline di-n-butylphthalate & 31 & 23 & 88 \\
\hline fluoranthene & 200 & 200 & 150 \\
\hline pyrene & 180 & 180 & 140 \\
\hline butylbenzylphthalate & 41 & 70 & 45 \\
\hline benz(a)anthracene & 130 & 98 & 72 \\
\hline chrysene & 180 & 140 & 100 \\
\hline bis(2-ethylhexyl)phthalate & 730 & 1,000 & 670 \\
\hline di-n-octylphthalate & ND & ND & ND \\
\hline benzo(b)fluoranthene & 210 & 160 & 130 \\
\hline benzo(k)fluoranthene & 100 & 100 & 75 \\
\hline benzo(a)pyrene & 100 & 89 & 65 \\
\hline indeno(1,2,3-cd)pyrene & 130 & 130 & 100 \\
\hline $\operatorname{dibenz}(\mathrm{a}, \mathrm{h})$ anthracene & 34 & 22 & 16 \\
\hline benzo $(\mathrm{g}, \mathrm{h}, \mathrm{i})$ perylene & 110 & 120 & 90 \\
\hline
\end{tabular}


Table 13. Hydrophobic U.S. Environmental Protection Agency priority pollutants detected in suspended-sediment samples collected during the February-March 1990 cruise.-Continued

\begin{tabular}{|c|c|c|c|}
\hline \multirow[b]{2}{*}{ Compound } & \multicolumn{3}{|c|}{ Sampling site } \\
\hline & $\begin{array}{l}\text { Mississippi River } \\
\text { at Helena, Ark. }\end{array}$ & $\begin{array}{l}\text { Mississippi River } \\
\text { above } \\
\text { Arkansas City, Ark. }\end{array}$ & $\begin{array}{c}\text { Mississippi River } \\
\text { below } \\
\text { Vicksburg, Miss. }\end{array}$ \\
\hline phenol & 62 & 15 & 15 \\
\hline benzene, 1,3-dichloro- & 0.71 & 0.23 & 0.26 \\
\hline benzene, 1,4-dichloro- & 2.9 & 1.3 & 1.7 \\
\hline benzene, 1,2-dichloro- & 2 & 0.42 & 0.62 \\
\hline nitrobenzene & ND & ND & ND \\
\hline benzene, 1,2,4-trichloro- & 7.5 & 3.9 & 4.1 \\
\hline naphthalene & 20 & 16 & 15 \\
\hline acenaphthylene & 20 & 14 & 13 \\
\hline dimethylphthalate & 8.6 & 6.6 & 7.5 \\
\hline acenaphthene & 6.4 & 4.2 & 5.4 \\
\hline toluene, 2,4-dinitro- & ND & $\mathrm{ND}$ & ND \\
\hline fluorene & 11 & 9.6 & 9.2 \\
\hline diethylphthalate & 8.7 & 5.4 & 7.4 \\
\hline hexachlorobenzene & 0.88 & 1.3 & ND \\
\hline phenanthrene & 89 & 72 & 63 \\
\hline anthracene & 26 & 17 & 16 \\
\hline di-n-butylphthalate & 33 & 18 & 21 \\
\hline fluoranthene & 110 & 100 & 100 \\
\hline pyrene & 96 & 87 & 96 \\
\hline butylbenzylphthalate & 220 & 59 & 47 \\
\hline benz(a)anthracene & 73 & 66 & 48 \\
\hline chrysene & 110 & 87 & 70 \\
\hline bis(2-ethylhexyl)phthalate & 11,200 & 820 & 560 \\
\hline di-n-octylphthalate & 270 & ND & ND \\
\hline benzo(b)fluoranthene & 110 & 90 & 110 \\
\hline benzo(k)fluoranthene & 53 & 74 & 65 \\
\hline benzo(a)pyrene & 57 & 42 & 44 \\
\hline indeno(1,2,3-cd)pyrene & 110 & 76 & 65 \\
\hline dibenz(a,h)anthracene & 21 & 13 & ND \\
\hline benzo(g,h,i)perylene & 110 & 72 & 61 \\
\hline
\end{tabular}


Table 13. Hydrophobic U.S. Environmental Protection Agency priority pollutants detected in suspended-sediment samples collected during the February-March 1990 cruise.-Continued

\begin{tabular}{|c|c|c|}
\hline \multirow[b]{2}{*}{ Compound } & \multicolumn{2}{|r|}{ Sampling site } \\
\hline & $\begin{array}{l}\text { Mississippi River } \\
\text { near } \\
\text { St. Francisville, La. }\end{array}$ & $\begin{array}{l}\text { Mississippi River } \\
\text { below } \\
\text { Belle Chasse, La. }\end{array}$ \\
\hline phenol & ND & 11 \\
\hline benzene, 1,3-dichloro- & 0.28 & 0.3 \\
\hline benzene, 1,4-dichloro- & 2.1 & 0.5 \\
\hline benzene, 1,2-dichloro- & 0.67 & 0.38 \\
\hline nitrobenzene & ND & ND \\
\hline benzene, 1,2,4-trichloro- & 3.8 & 2.6 \\
\hline naphthalene & 18 & 11 \\
\hline acenaphthylene & 14 & 8.3 \\
\hline dimethylphthalate & 17 & 13 \\
\hline acenaphthene & 4 & ND \\
\hline toluene, 2,4-dinitro- & ND & ND \\
\hline fluorene & 7.3 & 7 \\
\hline diethylphthalate & 14 & 14 \\
\hline hexachlorobenzene & ND & 1.6 \\
\hline phenanthrene & 51 & 48 \\
\hline anthracene & 14 & 14 \\
\hline di-n-butylphthalate & 26 & 30 \\
\hline fluoranthene & 89 & 61 \\
\hline pyrene & 84 & 54 \\
\hline butylbenzylphthalate & 74 & 70 \\
\hline benz(a)anthracene & 39 & 38 \\
\hline chrysene & 58 & 53 \\
\hline bis(2-ethylhexyl)phthalate & 780 & 520 \\
\hline di-n-octylphthalate & ND & ND \\
\hline benzo(b)fluoranthene & 70 & 50 \\
\hline benzo(k)fluoranthene & 48 & 37 \\
\hline benzo(a)pyrene & 23 & 49 \\
\hline indeno(1,2,3-cd)pyrene & 83 & 47 \\
\hline $\operatorname{dibenz}(\mathrm{a}, \mathrm{h})$ anthracene & 22 & 8.7 \\
\hline benzo(g,h,i)perylene & 79 & 47 \\
\hline
\end{tabular}


Hexachlorobenzene was targeted by both the halogenated organic compound analysis (by GC/NCI/MS) and the priority pollutant analysis (by GC/EI/MS). The detection limit for the priority pollutant technique was higher than the halogenated technique, and varied with sample size. For samples with data by both techniques, the values in microgram $/ \mathrm{kg}$ were compared. The GC/NCI/MS values were consistently slightly higher, but the variation of the values from the two techniques averaged about 15 percent of their mean.
The semiquantitative data for organochlorine compounds and herbicides are presented in table 14 for June 1989 and table 15 for February-March 1990. Recoveries of these polar compounds, using the extraction and fractionation technique that targeted isolation of hydrophobic organic compounds, are unknown.

Table 14. Semiquantitative screening for organochlorine compounds and herbicides found in suspended-sediment samples collected during the June 1989 cruise.

[All concentrations in micrograms per kilogram dry sediment; ND, not detected]

\begin{tabular}{|c|c|c|c|}
\hline \multirow[b]{2}{*}{ Compound } & \multicolumn{3}{|c|}{ Sampling site } \\
\hline & $\begin{array}{l}\text { Mississippi River } \\
\text { near Winfield, Mo. }\end{array}$ & $\begin{array}{l}\text { Illinois River at } \\
\text { Hardin, III. }\end{array}$ & $\begin{array}{c}\text { Missouri River at } \\
\text { Hermann, Mo. }\end{array}$ \\
\hline \multicolumn{4}{|c|}{ Organochlorine compounds } \\
\hline Pentachloronitrobenzene & ND & ND & ND \\
\hline DDE & 12 & 8.7 & 0.98 \\
\hline DDD & 7.3 & 4.3 & 2.5 \\
\hline DDT & 13 & 22 & 1.1 \\
\hline \multicolumn{4}{|c|}{ Herbicides } \\
\hline Trifluralin & 0.34 & 0.81 & 0.39 \\
\hline Atrazine & ND & 1.6 & 0.6 \\
\hline Alachlor & 10 & 9.5 & 3.2 \\
\hline Metolachlor & 2.3 & 0.22 & 2.9 \\
\hline \multicolumn{4}{|c|}{ Carbamate } \\
\hline \multirow[t]{2}{*}{ Eptan (EPTC) } & ND & ND & 2.7 \\
\hline & $\begin{array}{l}\text { Mississippi River at } \\
\text { St. Louis, Mo. }\end{array}$ & $\begin{array}{l}\text { Mississippi River at } \\
\text { Thebes, III. }\end{array}$ & $\begin{array}{l}\text { Ohio River at } \\
\text { Olmsted, III. }\end{array}$ \\
\hline Pentachloronitrobenzene & ND & ND & ND \\
\hline DDE & ND & 2.2 & 5 \\
\hline DDD & ND & 3.4 & 10 \\
\hline DDT & ND & 1 & 40 \\
\hline \multicolumn{4}{|c|}{ Herbicides } \\
\hline Trifluralin & 0.17 & ND & 7 \\
\hline Atrazine & 0.88 & ND & 1.4 \\
\hline Alachlor & 4.8 & 2.8 & 420 \\
\hline Metolachlor & 1 & 0.74 & 34 \\
\hline \multicolumn{4}{|c|}{ Carbamate } \\
\hline Eptan (EPTC) & ND & ND & ND \\
\hline
\end{tabular}


Table 14. Semiquantitative screening for organochlorine compounds and herbicides found in suspended-sediment samples collected during the June 1989 cruise.-Continued

\begin{tabular}{|c|c|c|c|}
\hline \multirow[b]{2}{*}{ Compound } & \multicolumn{3}{|c|}{ Sampling site } \\
\hline & $\begin{array}{c}\text { Mississippi River } \\
\text { below Hickman, Ky. }\end{array}$ & $\begin{array}{l}\text { Mississippi River at } \\
\text { Fulton, Tenn. }\end{array}$ & $\begin{array}{l}\text { Mississippi River at } \\
\text { Helena, Ark. }\end{array}$ \\
\hline Pentachloronitrobenzene & ND & ND & ND \\
\hline DDE & ND & 2.4 & 6.2 \\
\hline DDD & ND & 5.9 & 17 \\
\hline DDT & ND & 1.4 & 46 \\
\hline \multicolumn{4}{|c|}{ Herbicides } \\
\hline Trifluralin & ND & 0.94 & 0.73 \\
\hline Atrazine & 6 & ND & ND \\
\hline Alachlor & 30 & 12 & 13 \\
\hline Metolachlor & 3.1 & 1.5 & 3.7 \\
\hline \multicolumn{4}{|c|}{ Carbamate } \\
\hline \multirow[t]{2}{*}{ Eptan (EPTC) } & ND & ND & ND \\
\hline & $\begin{array}{c}\text { White River at Mile } \\
\text { 11.5, Ark. }\end{array}$ & $\begin{array}{l}\text { Arkansas River at } \\
\text { Pendleton, Ark. }\end{array}$ & $\begin{array}{c}\text { Mississippi River } \\
\text { above Arkansas City, } \\
\text { Ark. }\end{array}$ \\
\hline \multicolumn{4}{|c|}{ Organochlorine compounds } \\
\hline Pentachloronitrobenzene & $\mathrm{ND}$ & ND & ND \\
\hline DDE & 7.9 & 4 & 2.2 \\
\hline DDD & 9.1 & 2.8 & 16 \\
\hline DDT & 6.3 & 0.98 & 17 \\
\hline \multicolumn{4}{|c|}{ Herbicides } \\
\hline Trifluralin & 0.14 & ND & 0.79 \\
\hline Atrazine & ND & ND & ND \\
\hline Alachlor & ND & ND & 10 \\
\hline Metolachlor & ND & ND & 3.4 \\
\hline \multicolumn{4}{|c|}{ Carbamate } \\
\hline \multirow[t]{2}{*}{ Eptan (EPTC) } & ND & ND & ND \\
\hline & $\begin{array}{l}\text { Yazoo River below } \\
\text { Steele Bayou, Miss. }\end{array}$ & $\begin{array}{c}\text { Mississippi River } \\
\text { below Vicksburg, } \\
\text { Miss. }\end{array}$ & $\begin{array}{l}\text { OutflowChannel near } \\
\text { Knox Landing, La. }\end{array}$ \\
\hline \multicolumn{4}{|c|}{ Organochlorine compounds } \\
\hline Pentachloronitrobenzene & 0.97 & ND & ND \\
\hline DDE & 18 & 1.8 & 16 \\
\hline DDD & 55 & 5.1 & 79 \\
\hline DDT & 100 & 0.38 & 23 \\
\hline \multicolumn{4}{|c|}{ Herbicides } \\
\hline Trifluralin & 0.39 & 0.11 & 1.2 \\
\hline Atrazine & 1.1 & ND & ND \\
\hline Alachlor & ND & 1.5 & 18 \\
\hline Metolachlor & 0.94 & 0.36 & 3.7 \\
\hline
\end{tabular}


Table 14. Semiquantitative screening for organochlorine compounds and herbicides found in suspended-sediment samples collected during the June 1989 cruise._-Continued

\begin{tabular}{|c|c|c|c|c|}
\hline \multirow[b]{2}{*}{ Compound } & \multicolumn{3}{|c|}{ Sampling site } & \\
\hline & $\begin{array}{l}\text { Yazoo River below } \\
\text { Steele Bayou, Miss. }\end{array}$ & $\begin{array}{c}\text { Mississippi River } \\
\text { below Vicksburg, } \\
\text { Miss. }\end{array}$ & $\begin{array}{l}\text { OutflowChannel near } \\
\text { Knox Landing, La. }\end{array}$ & \\
\hline \multicolumn{4}{|c|}{ Carbamate } & \\
\hline \multirow[t]{2}{*}{ Eptan (EPTC) } & ND & ND & ND & \\
\hline & $\begin{array}{l}\text { Mississippi River } \\
\text { near } \\
\text { St. Francisville, La. }\end{array}$ & $\begin{array}{l}\text { Mississippi River } \\
\text { below } \\
\text { Belle Chasse, La. }\end{array}$ & Procedure blank & Procedure blank \\
\hline \multicolumn{5}{|c|}{ Organochlorine compounds } \\
\hline Pentachloronitrobenzene & ND & ND & ND & ND \\
\hline DDE & 16 & 4.6 & ND & ND \\
\hline DDD & 34 & 13 & ND & ND \\
\hline DDT & 16 & 9.9 & ND & ND \\
\hline \multicolumn{5}{|c|}{ Herbicides } \\
\hline Trifluralin & 0.84 & 0.22 & ND & ND \\
\hline Atrazine & 0.31 & ND & ND & ND \\
\hline Alachlor & 9 & 2.7 & ND & ND \\
\hline Metolachlor & 2 & 0.89 & ND & ND \\
\hline \multicolumn{5}{|c|}{ Carbamate } \\
\hline Eptan (EPTC) & ND & ND & ND & ND \\
\hline
\end{tabular}


Table 15. Semiquantitative screening for organochlorine compounds and herbicides found in suspended-sediment samples collected during the February-March 1990 cruise.

[All concentrations in micrograms per kilogram dry sediment; ND, not detected]

\section{Sampling site}

\begin{tabular}{|c|c|c|c|}
\hline Compound & Ohio River at Olmsted, III. & $\begin{array}{l}\text { Mississippi River below } \\
\text { Hickman, Ky. }\end{array}$ & $\begin{array}{l}\text { Mississippi River below } \\
\text { Fulton, Tenn. }\end{array}$ \\
\hline \multicolumn{4}{|c|}{ Organochlorine compounds } \\
\hline Pentachloronitrobenzene & $\mathrm{ND}$ & ND & ND \\
\hline DDE & ND & 11 & ND \\
\hline DDD & ND & 7.8 & ND \\
\hline DDT & 16 & 40 & ND \\
\hline \multicolumn{4}{|c|}{ Herbicides } \\
\hline Trifluralin & 1.9 & 0.96 & 1.1 \\
\hline Atrazine & 3.1 & $\mathrm{ND}$ & 2.7 \\
\hline Alachlor & ND & 4.3 & 5.2 \\
\hline Metolachlor & ND & 1.5 & ND \\
\hline \multicolumn{4}{|c|}{ Carbamate } \\
\hline \multirow[t]{2}{*}{ Eptan (EPTC) } & ND & ND & ND \\
\hline & $\begin{array}{l}\text { Mississippi River at } \\
\text { Helena, Ark. }\end{array}$ & $\begin{array}{l}\text { Mississippi River above } \\
\text { Arkansas City, Ark. }\end{array}$ & $\begin{array}{l}\text { Mississippi River below } \\
\text { Vicksburg, Miss. }\end{array}$ \\
\hline \multicolumn{4}{|c|}{ Organochlorine compounds } \\
\hline Pentachloronitrobenzene & ND & $\mathrm{ND}$ & ND \\
\hline DDE & ND & 3.4 & 18 \\
\hline DDD & ND & 5.7 & 41 \\
\hline DDT & ND & 18 & 13 \\
\hline \multicolumn{4}{|c|}{ Herbicides } \\
\hline Trifluralin & 0.89 & 0.91 & 0.85 \\
\hline Atrazine & ND & 1.2 & ND \\
\hline Alachlor & 2.8 & 2.9 & 2.6 \\
\hline Metolachlor & $\mathrm{ND}$ & 1.2 & ND \\
\hline \multicolumn{4}{|c|}{ Carbamate } \\
\hline Eptan (EPTC) & ND & ND & ND \\
\hline
\end{tabular}


Table 15. Semiquantitative screening for organochlorine compounds and herbicides found in suspended-sediment samples collected during the February-March 1990 cruise._-Continued

\begin{tabular}{|c|c|c|}
\hline \multirow[b]{2}{*}{ Compound } & \multicolumn{2}{|r|}{ Sampling site } \\
\hline & $\begin{array}{l}\text { Mississippi River near } \\
\text { St. Francisville, La. }\end{array}$ & $\begin{array}{l}\text { Mississippi River below } \\
\text { Belle Chasse, La. }\end{array}$ \\
\hline \multicolumn{3}{|c|}{ Organochlorine compounds } \\
\hline Pentachloronitrobenzene & ND & ND \\
\hline DDE & 24 & 14 \\
\hline DDD & 57 & 44 \\
\hline DDT & 21 & 9.3 \\
\hline \multicolumn{3}{|c|}{ Herbicides } \\
\hline Trifluralin & 0.69 & 0.55 \\
\hline Atrazine & ND & 1.6 \\
\hline Alachlor & 2.5 & 2 \\
\hline Metolachlor & ND & 0.72 \\
\hline \multicolumn{3}{|c|}{ Carbamate } \\
\hline Eptan (EPTC) & ND & ND \\
\hline
\end{tabular}




\section{Literature Cited}

Alford-Stevens, A.L. and Budde, W.L., 1988, Determination of polychlorinated compounds (dioxins, furans, and biphenyls) by level of chlorination with automated interpretation of mass spectrometric data, in Lichtenberg, J.J., Winter, J.A., Weber, C.I., and Fradkin, L., eds., Chemical and Biological Characterization of Sludges, Sediments, Dredge Spoils, and Drilling Muds, American Society for Testing and Materials, Special Technical Publication 976: Philadelphia, American Society for Testing and Materials, p. 204-212.

Barthel, W.F., Hawthorne, J.C., Ford, J.H., Bolton, G.C., McDowell, L.L., Grissinger, E.H., and Parsons, D.A., 1969, Pesticides in Water-Pesticide residues in sediments of the lower Mississippi River and its tributaries: Pesticides Monitoring Journal, v. 3, no. 1, p. 8-66.

DeLeon, R.I., Byrne, C.J., Peuler, E.A., Antoine, S.R., Schaeffer, J., and Murphy, R.C., 1986, Trace organic and heavy metal pollutants in the Mississippi River: Chemosphere, v. 15 , no. 6 , p. $795-805$.

Demas, C.R., and Curwick, P.B., 1987, Suspended-sediment, bottom-material, and associated chemical data from the lower Mississippi River, Louisiana: Baton Rouge, Louisiana Department of Transportation and Development, Louisiana Office of Public Works, Water Resources Basic Records Report no. 14, 117 p.

Demas, C.R., and Curwick, P.B., 1988, Suspended-sediment and associated chemical data from the lower Mississippi River, Louisiana: Baton Rouge, Louisiana Department of Transportation and Development, Louisiana Office of Public Works, Water Resources Technical Report no. 45, 44 p.

Erhardt-Zabik, S., Watson, J.T., and Zabik, M.J., 1990, Selective sensitivity of highly chlorinated species in negative ion mass spectrometry-Implications for complex mixture analysis: Biomedical and Environmental Mass Spectrometry, v. 19, p. 101-108.

Everett, D.E., 1971, Hydrologic and quality characteristics of the lower Mississippi River: Baton Rouge, Louisiana Department of Public Works Technical Report no. 5, 48 p.

Federal Register, 1980, EPA-water quality criteria documents: availabliity. v. 45, no. 231, p. 79318-79379.

Grayman, W.M., 1985, Characterization of the water quality of the lower Mississippi River: U.S. Environmental Protection Agency, EPA/600/2-85/043, 107 p.

Helsel, D.R., 1990, Less than obvious - statistical treatment of data below the detection limit: Environmental Science and Technology, v. 24, no. 12, p. 1766-1774.
Helsel, D.R., and Cohn, T.A., 1988, Estimation of descriptive statistics for multiply censored water quality data: Water Resources Research, v. 24, no. 12, p. 1997-2004.

Keown, M.P., Dardeau, E.A., Jr., and Causey, E.M., 1981, Characterization of the suspended-sediment regime and bed-material gradation of the Mississippi River Basin: Potamology Program (P-1): U.S. Army Corps of Engineers, New Orleans District, v. 1 and v. 2, 874 p.

Keown, M.P., Dardeau, E.A., Jr., and Causey, E.M., 1986, Historic trends in the sediment flow regime of the Mississippi River: Water Resources Research, v. 22, no. 11, p. 15551564.

Leenheer, J.A., Meade, R.H., Taylor, H.E., and Pereira, W.E., 1989, Sampling, fractionation, and dewatering of suspended sediment from the Mississippi River for geochemical and trace-contaminant analysis in Mallard, G.E. and Ragone, S.E. eds., U.S. Geological Survey Toxic Substances Hydrology Program-Proceedings of the Technical Meeting, Phoenix, Arizona, September 26-30, 1988: U.S. Geological Survey Water-Resources Investigations Report 88-4220, p. 501-511.

Lytle, T.F., and Lytle, J.S., 1990, Contaminants in sediments from the central Gulf of Mexico: Estuaries, v. 13, no. 1, p. $98-111$.

Meade, R.H., 1985, Suspended sediment in the Amazon River and its tributaries in Brazil during 1982-1984: U.S. Geological Survey Open-File Report 85-492, 39 p.

Meade, R.H., and Parker, R.S., 1985, Sediment in rivers of the United States, in National Water Summary 1984: U.S. Geological Survey Water-Supply Paper 2275, p. 49-60.

Meade, R.H. and Stevens, H.H., Jr., 1990, Strategies and equipment for sampling suspended sediment and associated toxic chemicals in large rivers-with emphasis on the Mississippi River: Science of the Total Environment, v. 97/98, p. $125-135$.

Meade, R.H., Yuzyk, T.R., and Day, T.J., 1990, Movement and storage of sediment in rivers of the United States and Canada, Chapter 11 in The Geology of North America, v. O-1, Surface Water Hydrology: Boulder, Colorado, Geological Society of America, p. 255-280.

Merriman, J.C., 1988, Distribution of organic contaminants in water and suspended solids of the Rainy River: Water Pollution Research Journal of Canada, v. 23, no. 4, p. 590-600.

Moody, J.A., 1993, Evaluation of the Lagrangian sampling scheme for sampling the Mississippi River during 1987-90, U.S. Geological Survey Water Resources Investigations Report 93-4042, 31 p. 
Moody, J.A., and Meade, R.H., 1992, Hydrologic and sedimentologic data collected during three cruises at low water on the Mississippi River and some of its tributaries, July 1987-June 1988: U.S. Geological Survey Open-File Report 91-485, 143 p.

Moody, J.A., and Meade, R.H., 1993, Hydrologic and sedimentologic data collected during four cruises at high water on the Mississippi River and some of its tributaries, March 1989-June 1990: U.S. Geological Survey Open-File Report 92-651, $227 \mathrm{p}$.

Moody, J.A., and Troutman, B.M., 1992, Evaluation of the depth integration method of measuring water discharge: Journal of Hydrology, v. 135, p. 201-236.

Nordin, C.F., Cranston, C.C., and Mejia-B., A., 1983, New technology for measuring water and suspended sediment discharge of large rivers, in International Symposium on River Sedimentation, 2d, Nanjing, China: Beijing, Water Resources and Electric Power Press, p. 1145-1158.

Ongley, E.D., and Blachford, D.P., 1982, Application of continuous flow centrifugation to contaminant analysis of suspended sediment in fluvial systems: Environmental Technology Letters, v. 3, no. 5, p. 219-228.

Pereira, W.E., and Rostad, C.E., 1990, Occurrence, distributions and transport of herbicides and their degradation products in the lower Mississippi River and its tributaries: Environmental Science and Technology, v. 24, no. 9, p. $1400-1406$.

Pereira, W.E., Rostad, C.E., and Leiker, T.J., 1990, Distribution of agrochemicals in the lower Mississippi River and its tributaries: Science of the Total Environment, v. 97/98, p. 41-53.

Rees, T.F., Leenheer, J.A., and Ranville, J.F., 1991, Use of a single-bowl continuous-flow centrifuge for dewatering suspended sediments: effect on sediment physical and chemical characteristics: Hydrological Processes, v. 5, p. 201-214.

Rees, T.F., and Ranville, J.F., 1990, Collection and analysis of colloidal particles transported in the Mississippi River, U.S.A.: Journal of Contaminant Hydrology, v. 6, p. 241250.

Robbins, L.G., 1976, Suspended sediment and bed material studies on the lower Mississippi River: U.S. Army Corps of Engineers, Vicksburg District, Miss., Potamology Investigations Report 300-1, 28 p.

Schafer, M.L., Peeler, J.T., Gardner, W.S., and Campbell, J.E., 1969, Pesticides in drinking waters from the Mississippi and Missouri Rivers: Environmental Science and Technology, v. 3 , no. 12 , p. 1261-1269.
Taylor, H.E., Garbarino, J.R., and Brinton, T.I., 1990, The occurrence and distribution of trace metals in the Mississippi River and its tributaries: Science of the Total Environment, v. 97/98, p. 369-384.

U.S. Geological Survey, and Canada, Department of the Environment, 1988a, National Water Conditions: Reston, Virginia, U.S. Geological Survey, May 1988.

U.S. Geological Survey, and Canada, Department of the Environment, 1988, USGS National Water Conditions: Reston, Virginia, U.S. Geological Survey, June 1988.

Wells, F.C., 1980, Hydrology and water quality of the lower Mississippi River: Baton Rouge, Louisiana Department of Transportation and Development, Office of Public Works, Water Resources Technical Report no. 21, 83 p.

Wershaw, R.L., Fishman, M.J., Grabbe, R.R., and Lowe, L.E., 1983, Methods for the determination of organic substances in water and fluvial sediments: U.S. Geological Survey Open-File Report 82-1004, 173 p. 



\section{$\frac{\mathbb{2}}{3}$}

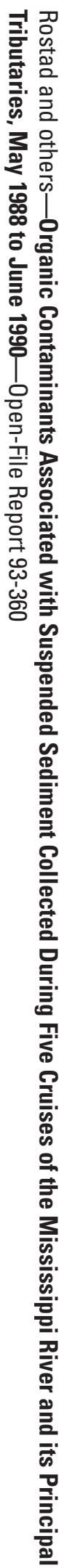

69 Printed on recycled paper 